Article

\title{
Analysis of Particulate Matter Concentration Variability and Origin in Selected Urban Areas in Poland
}

\author{
Izabela Sówka ${ }^{1, *}$, Anna Chlebowska-Styś ${ }^{1}$, Łukasz Pachurka ${ }^{2}$, Wioletta Rogula-Kozłowska ${ }^{3}$ (D) \\ and Barbara Mathews ${ }^{4}$ \\ 1 Faculty of Environmental Engineering, Wroclaw University of Science and Technology, \\ Wybrzeże Wyspiańskiego 27, 50-370 Wrocław, Poland; anna.chlebowska@pwr.edu.pl \\ 2 Galwanizer Ltd., Swidnicka Str. 38, 58-200 Dzierzoniow, Poland; lukasz.pachurka@pwr.edu.pl \\ 3 The Main School of Fire Service, Słowackiego Str. 52/54, 01-629 Warsaw, Poland; wrogula@sgsp.edu.pl \\ 4 Institute of Environmental Engineering, Polish Academy of Sciences in Zabrze, \\ M. Skłodowskiej-Curie 34 Str., 41-819 Zabrze, Poland; barbara.mathews@ipis.zabrze.pl \\ * Correspondence: izabela.sowka@pwr.edu.pl
}

Received: 15 September 2019; Accepted: 14 October 2019; Published: 16 October 2019

\begin{abstract}
The work presents the results of research and analyses related to measurements of concentration and chemical composition of three size fractions of particulate matter (PM), $\mathrm{PM}_{10}$, $\mathrm{PM}_{2.5}$ and $\mathrm{PM}_{1.0}$. The studies were conducted in the years 2014-2016 during both the heating and non-heating season in two Polish cities: Wrocław and Poznan. The studies indicate that in Wrocław and Poznań, the highest annual concentrations of particulate matter $\left(\mathrm{PM}_{1.0}, \mathrm{PM}_{2.5}\right.$, and $\left.\mathrm{PM}_{10}\right)$ were observed in 2016, and the mean concentrations were respectively equal to $18.16 \mu \mathrm{g} / \mathrm{m}^{3}, 30.88 \mu \mathrm{g} / \mathrm{m}^{3}$ and $41.08 \mu \mathrm{g} / \mathrm{m}^{3}$ (Wrocław) and $8.5 \mu \mathrm{g} / \mathrm{m}^{3}, 30.8 \mu \mathrm{g} / \mathrm{m}^{3}$ and $32.9 \mu \mathrm{g} / \mathrm{m}^{3}$ (Poznań). Conducted analyses of the chemical composition of the particulate matter also indicated higher concentrations of organic and elemental carbon (OC and EC), and water-soluble ions in a measurement series which took place in the heating season were studied. Analyses with the use of principal component analysis (PCA) indicated a dominating percentage of fuel combustion processes as sources of particulate matter emission in the areas considered in this research. Acquired results from these analyses may indicate the influence of secondary aerosols on air quality. In the summer season, a significant role could be also played by an influx of pollutants—-mineral dust—originating from outside the analyzed areas or from the resuspension of mineral and soil dust.
\end{abstract}

Keywords: $\mathrm{PM}_{10} ; \mathrm{PM}_{2.5} ; \mathrm{PM}_{1.0}$; chemical composition; $\mathrm{PCA}$; water-soluble ions; elemental and organic carbon; Wrocław; Poznań

\section{Introduction}

In the last few decades, concentrations of sulfur dioxide or nitrogen oxide within Europe, including Poland, decreased significantly [1]. However, there are many regions in Europe where standards established for particulate matter (PM) are still being exceeded, which negatively influences the health of people inhabiting those regions. Undesired effects are brought forth even by the mere presence of fine particles in the organism and in addition, their toxic influence is multiplied by heavy metals and polycyclic aromatic hydrocarbons, which are their carriers [2-7].

According to the European Environment Agency (EEA), in 2018, the standard permissible limit of days (in which the 24 hour average value of $\mathrm{PM}_{10}$ concentration is higher than $50 \mu \mathrm{g} / \mathrm{m}^{3}$ (the so called acceptable frequency of exceedance)), was exceeded in as many as 19 among 28 member states (19\% of all measurement stations) [8]. The highest air pollution levels in Europe are observed in the eastern 
and central part of the European continent, which includes Poland $[1,8,9]$. In the years 2010-2014, the highest annual average concentrations of $\mathrm{PM}_{10}$ in the air were observed in the following Polish cities: Kraków, Poznań, Wrocław and Warszawa. The lowest concentrations of particulate matter were determined in the cities of northern Europe, such as Denmark or Copenhagen [9]. The problem of polluted air is counteracted by the majority of Polish metropolitan areas, while at the same time the higher pollution concentrations and more frequent occurrences of smog episodes are confirmed in the southern part of the country [10-14]. Moreover, in the case of Polish metropolitan areas, there is a clear seasonal variability in concentrations of particulate matter. [15]. The condition described above is influenced by the topography and meteorological factors, but a large role is played by methods used to heat dwellings (dwelling-adjacent individual boiler rooms with hard or brown coal used as fuel)—so called low-stack emissions from municipal and household sectors [11,13,14,16-18].

Metropolitan areas present not only seasonal variability in pollutant concentration, but also daily variability, which is influenced by the daily rhythm of inhabitants commuting to work or schools. In this case, a large influence on the air quality originates from traffic emissions. Intensive car traffic in the morning and noon hours undoubtedly influences the increase in pollutant emissions in those hours and also affects the composition of particulate matter [9,15,19-21]. In the year 2014 in Poland, road transport was responsible for $22 \%$ of the total emissions of particulate matter and $59 \%$ of the emissions originated from other stationary sources, which included low-stack emissions [9].

In Poland an entity responsible for monitoring the air, as a part of state environmental monitoring (SEM), is the Chief Inspectorate of Environmental Protection (CIEP). In standard air monitoring, the research on $\mathrm{PM}_{10}$ particulate matter composition in urbanized areas is limited to analyses of $\mathrm{Cd}, \mathrm{Ni}$, $\mathrm{Pb}$, As and benzo(a)pyrene (BaP) [22], and in the case of the $\mathrm{PM}_{2.5}$ fraction, the measurement of its chemical composition is not carried out at urban background stations. It is a significant limitation, especially when it is necessary to determine the origins of the particulate matter in a specific urban area. Establishing the chemical composition of particulate matter enables us to indicate the sources of particulate matter emission, and as a consequence, it may aid efforts aiming to eliminate the problem of poor air quality.

Statistical methods find their use in the identification of emission sources through extraction of the most correlated factors, based on, among others, the concentrations of water-soluble ions, organic carbon (OC) and elemental carbon (EC), which subsequently enables us to classify specific factors and attribute them to a particular emission source (e.g., transport, power generation, industry). In this scope, statistical methods include, among others, principal component analysis (PCA) [23-26], which is one of the techniques used to determine the sources of particulate matter emission based on its chemical composition [14,27-30].

This work aimed to carry out a comparative analysis of the variability of concentration and composition of fine particulate matter in the area of Wrocław and Poznań city, as well as the identification of its sources. Wrocław and Poznan were selected due to the high population density and due to the fact that that little research has been done to date on the chemical characteristics of PM in these cities. In contrast to the areas of southern and central Poland, the areas of Lower Silesia and Greater Poland are regions where PM measurements are conducted, and their results are reported only to the extent necessary for routine air quality monitoring. In Poznań, chemical composition (macro components) of $\mathrm{PM}_{1}$ and $\mathrm{PM}_{2.5}$ is not recognized at all.

\section{Area and Methodology of the Research}

\subsection{Research Time Periods and Characteristics of Measurement Points}

In the case of our own studies carried out in Wrocław, the sample collection of $\mathrm{PM}_{10}, \mathrm{PM}_{2.5}$ and $\mathrm{PM}_{1}$ particulate matter took place at the measurement point located at Kosiby Street (Figure 1, Station 1) in the time periods: 26 June-26 July 2014 (summer 2014) and 7 January-7 February 2015 (winter 2015). Further studies of $\mathrm{PM}_{10}, \mathrm{PM}_{2.5}$ and $\mathrm{PM}_{1}$ were conducted in the time periods: 31 July-13 August 2015 (summer 2015), 9-26 January 2016 (winter 2016) and 9-23 May 2016 (spring 2016). 


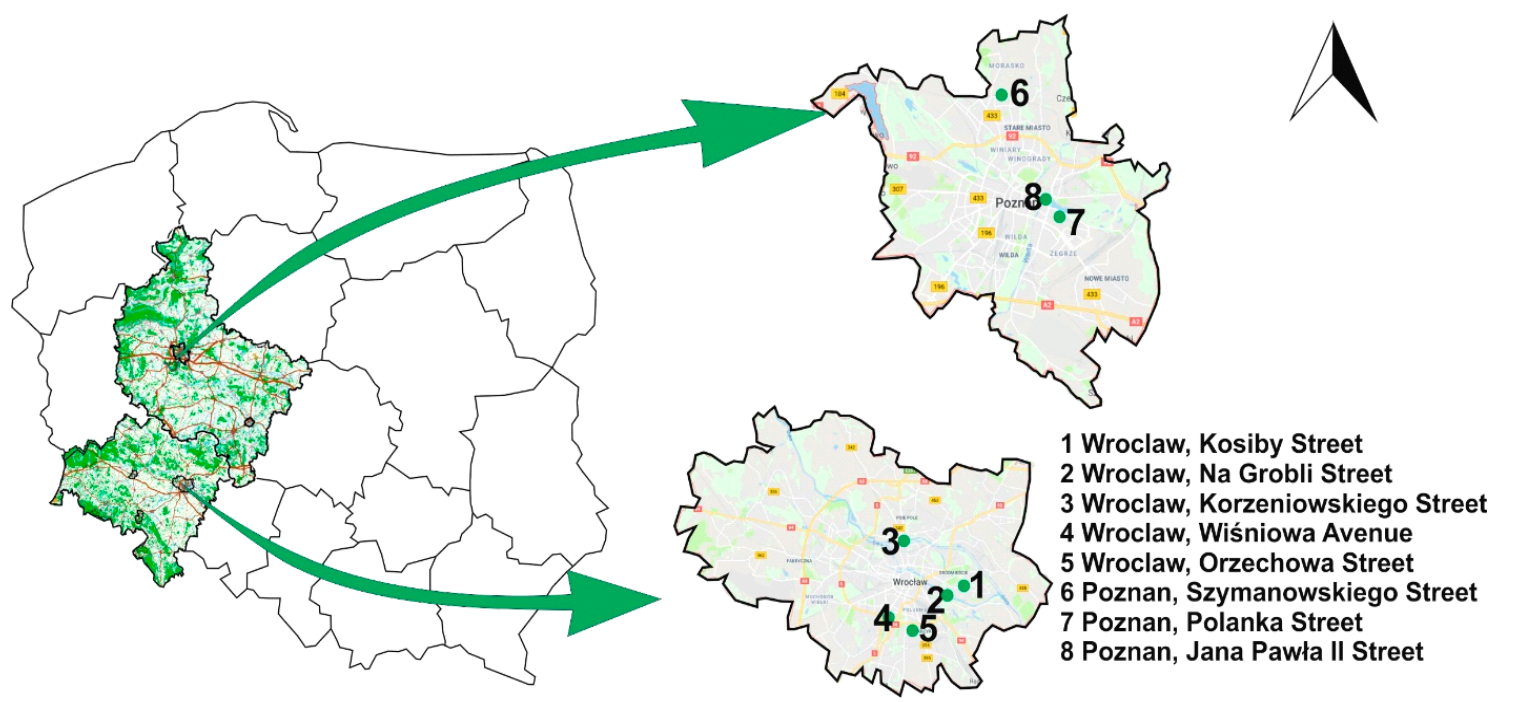

Figure 1. Localization of measurement points (source: own elaboration with use of Google Maps map backgrounds, access date: 28 August 2019).

The remaining data used in this work originates from the Voivodship Inspectorate for Environmental Protection (VIEP) measurement stations in Wrocław. Data from the years 2014-2016 originates from the station located at $\mathrm{Na}$ Grobli Street (Figure 1, Station 2). A manual gravimetric measurement method with $2.5 \mu \mathrm{m}$ fraction separation was used. At Wiśniowa Alley (Figure 1, Station 4), automatic measurement with $2.5 \mu \mathrm{m}$ fraction separation was used. Data from the 2015-2016 period was measured at the station at J. Conrada-Korzeniowskiego Street (Figure 1, Station 3) using automatic measurement. For the $\mathrm{PM}_{10}$ fraction, data from the 2014-2016 period originated from the measurement stations located at Orzechowa Street (Figure 1, Station 5) and J. Conrada-Korzeniowskiego Street (Figure 1, Station 3). These measurements were done with the use of the manual gravimetric method with separation of the $10 \mu \mathrm{m}$ fraction.

The measurement point in the studies representing urban background was stationed in the Biskupin estate in Wrocław at Kosiby 6/8 Street (Figure 1, Station 1) located in the southeastern part of the Śródmieście district, which encompasses a large number of green areas. The surroundings of the research station are an area of diverse character, which include parks, garden plots, low-rise buildings (semi-detached houses, villas) and high-rise buildings (blocks of flats). The measurement point was located about $5 \mathrm{~km}$ (in a straight line) from an electrical power and heating plant, about $0.1 \mathrm{~km}$ from the closest multi-family development (multi-family tenement house), about $180 \mathrm{~m}$ from another multi-family development (blocks of flats), and about $130 \mathrm{~m}$ from a road, whose traffic included passenger cars, trams, buses and bicycles.

The remaining measuring points are stations belonging to the VIEP in Wrocław and represent stations of urban background (Station 2, 3 and 5) and a station considered a road traffic station (Station 4). Stations 2 and 3 are located far from main traffic routes and are surrounded by green areas and multi-family dwellings. Station 4 at Wiśniowa Alley is located close to the main communication route in Wrocław, the intersection of Haller Street and Wiśniowa Alley, and is also located in the neighborhood of multi-family housings.

In the case of studies that took place in Poznań, two measurement campaigns were carried out: in the fall-winter season (25 October-22 November 2016) and in the summer season (5 June-2 July 2017) at three measurement stations (Figure 1, Stations 6-8).

Two measurement stations (at Szmanowskiego Street and at Polanka Street) belonged to the Provincial Environment Protection Inspector in Poznań; these were used as urban background stations. The station at Szymanowskiego Street (Station 6) borders with service and multi-family developments from the west, with multi-family buildings from the north and south and from the west and southwest 
directions, it is bordered by Podolany (a district of Poznań), which is characterized by single-family developments. At Podolany, only a manual measurement of $\mathrm{PM}_{10}$ particulate matter is carried out. The station at Polanka Street (Station 7) is surrounded by multi-family buildings, heated by local boiler rooms. Close to the north, there is also a man-made lake called Jezioro Maltańskie. From the east, there is a multi-family development heated by a district heating system and from the southwest, there is a large shopping mall. In the distance, about $800 \mathrm{~m}$ in the southeastern direction, there is a point emission source-the Malta-Décor company-which deals with the production of decorative paper. This work used the filters from the manual collection of $\mathrm{PM}_{2.5}$ from this station. Our own measurement station was located at Jana Pawła II 10 Street (Station 8). It is a divided street with separated tram trackage between the lanes. This segment is usually gridlocked. The selected location was supposed to reflect the influence of emissions from road traffic on air quality in this area. The area is directly bordered by the street. The device was installed at a distance of about $50 \mathrm{~m}$ from the street, on a green terrain belonging to the Poznan Supercomputing and Networking Center (PCSS). From the west, the station bordered directly with the street and right behind it is the Jezioro Maltańskie lake. From the north, the station bordered with green terrains, from the west with the Cybina river and from the south with the Poznan University of Technology Campus. At the station, the measurements were conducted manually by collection of three particulate matter fractions: $\mathrm{PM}_{10}, \mathrm{PM}_{2.5}$ and $\mathrm{PM}_{1.0}$.

The dates of measurements were intentionally planned for the heating season and the non-heating season in order to compare the chemical composition of particulate matter in two thermally different periods.

\subsection{Collection of Samples and Determination of Particulate Matter Concentration}

In order to collect $\mathrm{PM}_{1.0}, \mathrm{PM}_{2.5}$ and $\mathrm{PM}_{10}$ samples, Harvard type impactors (MS\&T Area Samplers, Air Diagnostics and Engineering, Inc., Harrison, ME, USA) were used. The airflow was forced by ultra-silent, oil-free vacuum pumps (Air Diagnostics and Engineering, air sampling pump, SP-280E model, Harrison, USA). Quartz fiber filters-Whatman QM-A (Wathaman Healthcare UK Limited, Amersham Place, Little Chalfont, Buckinghamshire, UK)with diameter of $37 \mathrm{~mm}$ were used as a substrate. The flow rate during sample collection was respectively equal to: samples $\leq 1.0 \mu \mathrm{m}-23 \mathrm{dm}^{3} / \mathrm{min}$, samples $\leq 2.5 \mu \mathrm{m}$ and $\leq 10 \mu \mathrm{m}-10 \mathrm{dm}^{3} / \mathrm{min}$. The volume of pumped air was controlled by an Actaris type flowmeter. The time of sample collection was $24 \mathrm{~h}$. The measurement of particulate matter was carried out with use of the gravimetric method in accordance with the PN-EN 12341: 2014 standard.

\subsection{Analysis of OC and EC Content in Particulate Matter Samples}

In order to determine organic carbon (OC) and elemental carbon (EC) in particulate matter samples, a thermo-optic analyzer of organic and elemental carbon (Model 4L Main Oven Assembly, Sunset Laboratory Inc., Tigard, OR, USA) with flame ionization detection (FID) was used. Samples of particulate matter, in the form of quartz filter specimens with an area of $1 \mathrm{~cm}^{2}$, were subjected to an analysis composed of two stages. First, by the gradual heating of the sample in a stream of helium, the organic fraction (OC) was released from the filter. In the following stage, a specimen of the filter was heated in an oxidizing mixture of helium and oxygen in order to release elemental carbon (EC). The heating of the examined samples progressed in accordance with the parameters determined in a specific measurement protocol. Compounds separated from the sample during subsequent heating stages in the furnace, in oxidizing conditions and with the presence of magnesium oxide, were transformed in stoichiometric ratio in relation to $\mathrm{CO}_{2}$. Carbon dioxide produced during the analysis was further reduced in a methanizer, in the presence of a hydrogen and a nickel catalyst, to methane, which was measured with the use of FID. Based on transmittance measurement which was done during the thermo-optic analysis with the use of a red-light laser beam (thermal optical transmittance (TOT)), the corrections for the determined contents of OC and EC were made. The last stage of the measurement process was the inclusion of a fixed volume loop in order to inject an external standard at the end of each analysis, which enabled us to provide optimal and stable conditions for the measurement, increasing the repeatability of the whole analytical method. 
With the use of the carbon analyzer, it is possible to take measurements in accordance with several standard temperature protocols, which differ from each other in the values of temperature thresholds, their number and duration. The analysis for this work was carried out using the "EUSAAR_2" protocol, which was designed as the suggested standard method for European measurement stations as a part of a European Supersites for Atmospheric Aerosol Research (EUSAAR) project.

Certified gases from Air Liquide (Cracow, Poland) were used to conduct analyses.

Validation parameters for the methods used are as follows:

1. Total measurement uncertainty of $\mathrm{EC}$ in $\mathrm{PM}_{2.5}$ particulate matter: $5 \%$;

2. EC limit of detection (LOD): $0.1 \mu \mathrm{g} / \mathrm{cm}^{2}$;

3. Total measurement uncertainty of $\mathrm{OC}$ in $\mathrm{PM}_{2.5}$ particulate matter: $5 \%$;

4. OC limit of detection (LOD): $0.47 \mu \mathrm{g} / \mathrm{cm}^{2}$.

\subsection{Analysis of the Content of Ions Soluble in Water in Samples of Particulate Matter}

Determination of water-soluble ions in samples of particulate matter deposited on filters consisted of extracting anions and cations from particulate matter and in deionized water and later determining their content in water extracts. The extraction of ions was performed with the use of a vortexer (12 h) in a cold room $\left(\leq 18^{\circ} \mathrm{C}\right)$ at 60 cycles per minute. Moreover, before the agitation process, the samples of particulate matter were subjected to ultrasound for $1 \mathrm{~h}$ in a water bath $\left(\right.$ at $\left.\leq 27^{\circ} \mathrm{C}\right)$. After the agitation process, acquired extracts were cleansed with the use of micropore polyethersulfone (PES) syringe filters.

The content of ions acquired from water extracts was determined with the use of the ion chromatography method. In order to determine anions $\left(\mathrm{F}^{-}, \mathrm{Cl}^{-}, \mathrm{NO}_{3}{ }^{-}, \mathrm{PO}_{4}{ }^{3-}, \mathrm{SO}_{4}{ }^{2-}\right)$ and cations $\left(\mathrm{Na}^{+}, \mathrm{NH}_{4}{ }^{+}, \mathrm{K}^{+}, \mathrm{Ca}^{2+}, \mathrm{Mg}^{2+}\right)$ in samples of particulate matter, authors used chromatographs of Dionex ICS 1100 type (Thermo Scientific company, USA) with a dual piston serial pump, automatic electrolytic suppression, and vacuum eluent degassing before the guard column and thermostating columns.

Chromeleon ${ }^{\circledR}$ SE (version 7, Thermo Scientific company, USA) dedicated software was used in order to operate the chromatograph. Only reagents with purity of at least p.a. grade were used in the analysis and the solutions for the preparation of calibration curves and control samples were done based on LGC standards of known uncertainty and concentration equal to $1 \mathrm{~g} / \mathrm{l}$.

Limits of detections were at the following levels: $0.01 \mathrm{mg} / \mathrm{dm}^{3}$ for $\mathrm{NH}_{4}{ }^{+}, 0.20 \mathrm{mg} / \mathrm{dm}^{3}$ for $\mathrm{Na}^{+}$ and $\mathrm{Mg}^{2+}, 0.22 \mathrm{mg} / \mathrm{dm}^{3}$ for $\mathrm{Ca}^{2+}, 0.25 \mathrm{mg} / \mathrm{dm}^{3}$ for $\mathrm{K}^{+}, 0.06 \mathrm{mg} / \mathrm{dm}^{3}$ for $\mathrm{NO}_{3}{ }^{-}, 0.07 \mathrm{mg} / \mathrm{dm}^{3}$ for $\mathrm{F}^{-}$and $\mathrm{Cl}^{-}, 0.10 \mathrm{mg} / \mathrm{dm}^{3}$ for $\mathrm{SO}_{4}{ }^{2-}$ and $\mathrm{PO}_{4}{ }^{3-}$.

\subsection{Analysis of Main Components}

This work presents the results of the PCA analyses carried out based on the determination of concentrations of organic carbon, elemental carbon, the following anions: $\mathrm{F}^{-}, \mathrm{Cl}^{-}, \mathrm{NO}_{3}{ }^{-}, \mathrm{PO}_{4}{ }^{3-}, \mathrm{SO}_{4}{ }^{2-}$ and the following cations: $\mathrm{Na}^{+}, \mathrm{NH}_{4}{ }^{+}, \mathrm{K}^{+}, \mathrm{Mg}^{2+}, \mathrm{Ca}^{2+}$ for measurements done at the stations at Kosiby Street in Wrocław (Station 1), Polanka Street (Station 7) and Jana Pawła II Street (Station 8) in Poznań, which respectively represent urban background stations and traffic stations. The calculations assumed varimax normalized rotation and that the factor loadings exceeding 0.7 are the most significant for each principal component [31]. Because of the short time of measurement campaigns carried out in Wrocław, acquired measurement data was merged into seasons with a similar period of concluded measurements, e.g., spring-summer season (non-heating season: Series 1 (summer) 2014; Series 3 (summer) 2015; Series 5 (spring) 2016) and fall-winter season (heating season: Series 2 (winter) 2015; Series 4 (winter) 2016). In the case of Poznan, the analysis was performed for two measurement stations with separation for two thermal seasons.

\section{Result and Discussion}

\subsection{Analysis of Variability in Concentration of Particulate Matter in Wrocław and Poznań}

Analysis of annual average values of concentrations acquired as a part of SEM in the years 2014-2016 in Wrocław and Poznań, alongside averaged values for the heating season (December-March) and the 
non-heating season (April-September) are presented in Figure 2. Pursuant to the regulation of the Minister for Environmental Protection [22], the permissible annual average concentration of $\mathrm{PM}_{2.5}$ in the air is equal to $25 \mu \mathrm{g} / \mathrm{m}^{3}$; in 2014 the applicable margin of tolerance was equal to $1 \mu \mathrm{g} / \mathrm{m}^{3}$. In the case of $\mathrm{PM}_{10}$ particulate matter, the law sets out two permissible values: annual average value equal to $40 \mu \mathrm{g} / \mathrm{m}^{3}$ and permissible number of days with $24 \mathrm{~h}$ average value exceeding $50 \mu \mathrm{g} / \mathrm{m}^{3}$. In accordance with the numbers described above, in 2014-2016, the analysis of data indicates that the standard for $\mathrm{PM}_{2.5}$ particulate matter was exceeded three-fold in Wrocław (each time at the station at Wiśniowa Alley-Station 4). In Poznań, the limits were not exceeded. However, the annual average values were closing in on the permissible value threshold. In Poznań as in Wrocław, significantly higher values of particulate matter were observed in the heating season. The values were twice as high than in the summer season. A similar situation occurs in other Polish urban areas [10,18,32,33].

The analyses of the studies carried out in Wrocław (Station 1) indicate that the largest concentrations of $\mathrm{PM}_{10}$ particulate matter were recorded during the studies carried out in the heating season in the winter of 2016. The maximum concentration of the $\mathrm{PM}_{10}$ fraction at that time was equal to $97.81 \mu \mathrm{g} / \mathrm{m}^{3}$ (Table 1). Moreover, for the fraction studied in that research period, the authors observed the highest standard deviation $( \pm 22.98)$ for specific concentration values of the analyzed period. A large standard deviation ( \pm 10.66 ) was recorded for $\mathrm{PM}_{1.0}$ particulate matter. The results acquired in that measurement series for the studied fraction $\left(\mathrm{PM}_{1.0}\right)$ were contained within the range of $2.84-38.20 \mu \mathrm{g} / \mathrm{m}^{3}$ [34].

In the case of Poznan, the average concentration of $\mathrm{PM}_{10}$ in the winter season was higher at the Szymanowskiego Street station. However, during the measurement series, the concentration levels at both stations were at a similar level (Table 2). For the station at Jana Pawła II Street (Station 8), an average concentration of $\mathrm{PM}_{10}$ in the summer season was $35 \%$ lower than in the first measurement series; moreover, in the case of the station at Szymanowskiego Street (Station 6), the concentration in the second measurement series was lower than the average concentration in the first measurement series by as much as $55 \%$. Perhaps this phenomenon is related to the phenomenon of low-stack emissions. The surroundings of the station at Szymanowskiego Street are composed mainly of single-family buildings, and the method of heating these houses in the heating season affects the air quality in this case. However, it must be noted that the average concentration of $\mathrm{PM}_{10}$ in the summer season at the station at Szymanowskiego Street was lower than at the station at Jana Pawła II Street. This situation also confirms that elimination of this factor (heating of the buildings) affects the air quality in a given area. The levels of $\mathrm{PM}_{10}$ pollution at both stations were close to the concentrations of $\mathrm{PM}_{10}$ observed in the same time periods in the previous years of measurements carried out by VIEP in the cities of Wielkopolska, with the exception of Kalisz (where there are specific conditions for the dispersion of pollutants) $[17,32]$. Concentrations of $\mathrm{PM}_{2.5}$ during the first measurements series ranged from $2.2 \mu \mathrm{g} / \mathrm{m}^{3}$ to $39.9 \mu \mathrm{g} / \mathrm{m}^{3}$ at the station at Jana Pawła II Street (Station 8). At the station at Polanka Street (Station 7), the concentrations ranged from $7.2 \mu \mathrm{g} / \mathrm{m}^{3}$ to $88.5 \mu \mathrm{g} / \mathrm{m}^{3}$. The average concentration was respectively equal to $15.2 \mu \mathrm{g} / \mathrm{m}^{3}$ for the station at Jana Pawła II Street and $30.8 \mu \mathrm{g} / \mathrm{m}^{3}$ for the station at Polanka Street. Concentrations noted during the second measurement series (summer period) were lower and ranged from $1.2 \mu \mathrm{g} / \mathrm{m}^{3}$ to $40.3 \mu \mathrm{g} / \mathrm{m}^{3}$ at the station at Jana Pawła II Street (Station 8) and from $7.2 \mu \mathrm{g} / \mathrm{m}^{3}$ to $17.1 \mu \mathrm{g} / \mathrm{m}^{3}$ at the station at Polanka Street (Station 7). The average concentrations of $\mathrm{PM}_{2.5}$ during the second measurement series at both stations were very similar and equal to $10.4 \mu \mathrm{g} / \mathrm{m}^{3}$ at Jana Pawła II Street and $11.0 \mu \mathrm{g} / \mathrm{m}^{3}$ at Polanka Street. Thus, the average concentration of $\mathrm{PM}_{2.5}$ at Jana Pawła II Street, in the summer season, was 32\% lower than in the winter season, and at the station at Polanka Street, the concentration was lower by as much as $64 \%$. At the station at Jana Pawła II Street, which is treated as a so-called road traffic station and was established to determine how emission from road traffic influences the air quality, we did not observe as distinctive differences in the concentrations of $\mathrm{PM}_{10}$ and $\mathrm{PM}_{2.5}$ between seasons, as we did for the two remaining background stations. However, it should be highlighted that the levels of particulate matter concentration in the winter season at every station were considerably higher than concentrations determined by World Health Organization (WHO) as safe for the health and life of people $\left(\mathrm{PM}_{10}-20 \mu \mathrm{g} / \mathrm{m}^{3}, \mathrm{PM}_{2.5}-10 \mu \mathrm{g} / \mathrm{m}^{3}\right)$ [35]. 


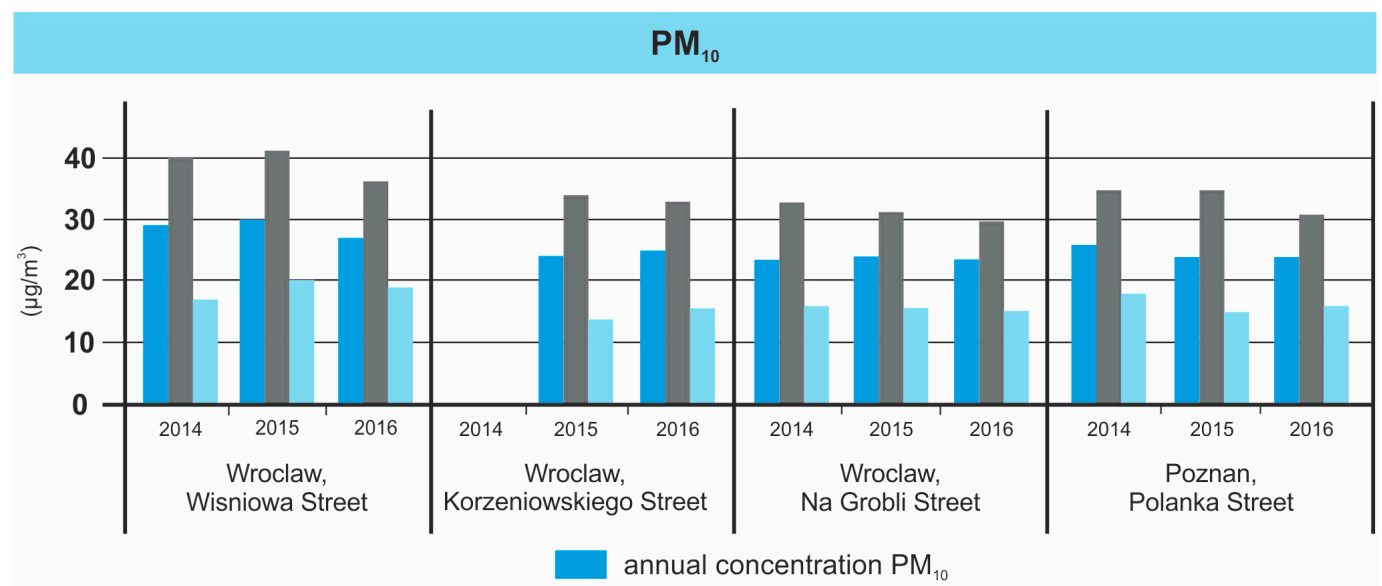

average concentration of $\mathrm{PM}_{10}$ in heating season average concentration of $\mathrm{PM}_{10}$ in non-heating season
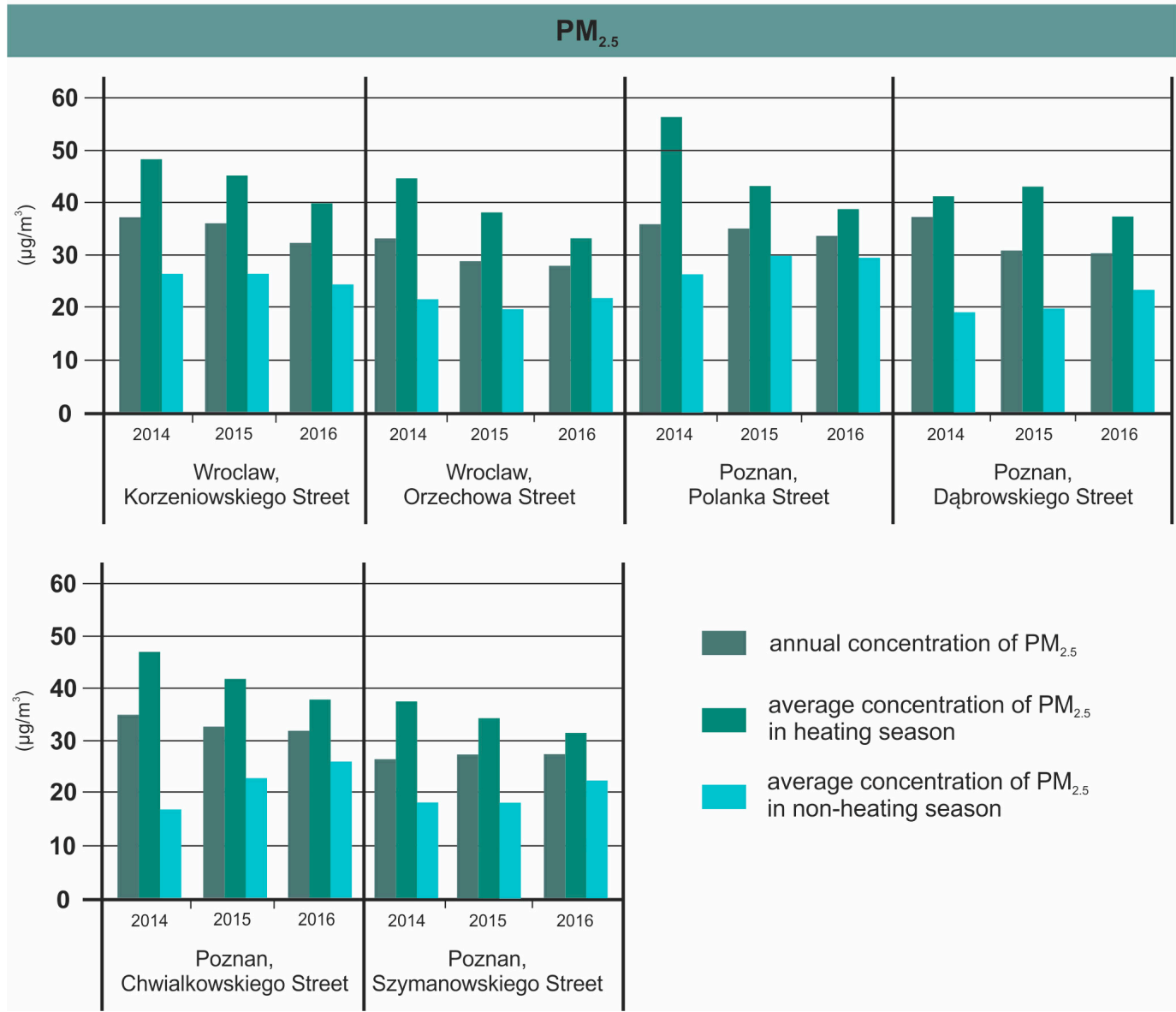

annual concentration of $\mathrm{PM}_{2.5}$ average concentration of $\mathrm{PM}_{2.5}$ in heating season

average concentration of $\mathrm{PM}_{2.5}$ in non-heating season

Figure 2. Mean annual concentration of particulate matter (PM) $\left(\mathrm{PM}_{2.5}\right.$ and $\left.\mathrm{PM}_{10}\right)$, averaged for the heating and non-heating seasons in Wrocław and Poznań, calculated on the basis of measurements carried out as a part of state environmental monitoring (SEM) (measurement points 2-7) (source: own elaboration based on Chief Inspectorate of Environmental Protection (CIEP) data).

Twenty-four-hour concentrations of $\mathrm{PM}_{1.0}$ in the winter season ranged from $2.47 \mu \mathrm{g} / \mathrm{m}^{3}$ to $22.87 \mu \mathrm{g} / \mathrm{m}^{3}$ and in the summer season from $2.72 \mu \mathrm{g} / \mathrm{m}^{3}$ to $10.35 \mu \mathrm{g} / \mathrm{m}^{3}$. The average concentration in the winter season was equal to $8.50 \mu \mathrm{g} / \mathrm{m}^{3}$ and in the summer season it was lower by $33 \%$ and equal to $5.72 \mu \mathrm{g} / \mathrm{m}^{3}$. The differences in $\mathrm{PM}_{1.0}$ concentrations between seasons are not as large as in the case of remaining two fractions; however, in the winter season, the concentrations are generally higher which is related to the origins of the finest ambient particles emitted primarily from fossil fuel 
(solid and liquid) and biomass combustion [36]. It is confirmed that in the winter season, there is an increase in the emission of gaseous precursors of $\mathrm{PM}_{1.0}$; therefore, it is obvious that the concentration of the finest ambient particles is increasing simultaneously. The concentrations of $\mathrm{PM}_{1.0}$ in Poznan are comparable to concentrations measured in other Polish cities and also higher than in the countries of western Europe [35,37]. High concentrations of $\mathrm{PM}_{1.0}$ in cities are related to the presence of many emission sources in those areas. It is however necessary to mention that high concentrations of $\mathrm{PM}_{1.0}$ in Poland are also confirmed in rural and suburban stations. This is most likely related to the process of transportation of $\mathrm{PM}_{1.0}$ from other areas, often very distant ones. The finest fraction of particulate matter may be present in the atmosphere for a long time; therefore, it may be transported a long distance [38]. Higher concentrations of particulate matter in the heating season in Poland are confirmed by numerous studies $[29,39,40]$.

Table 1. Descriptive statistics calculated for $\mathrm{PM}_{10}, \mathrm{PM}_{2.5}$ and $\mathrm{PM}_{1.0}$ concentrations for measurement point 1 located in Wrocław [34,41-43]. All values in this table are given in $\mu \mathrm{g} / \mathrm{m}^{3}$.

\begin{tabular}{cccccccccc}
\hline Year & \multicolumn{3}{c}{$\mathbf{2 0 1 4}$} & \multicolumn{3}{c}{$\mathbf{2 0 1 5}$} & \multicolumn{3}{c}{$\mathbf{2 0 1 6}$} \\
& $\mathrm{PM}_{1.0}$ & $\mathrm{PM}_{2.5}$ & $\mathrm{PM}_{10}$ & $\mathrm{PM}_{1.0}$ & $\mathrm{PM}_{2.5}$ & $\mathrm{PM}_{10}$ & $\mathrm{PM}_{1.0}$ & $\mathrm{PM}_{2.5}$ & $\mathrm{PM}_{10}$ \\
\hline Descriptive Statistics & & \multicolumn{7}{c}{ Heating } & Season (Winter) \\
Minimum & - & - & - & 3.58 & 4.58 & - & 2.84 & 2.09 & 11.58 \\
Maximum & - & - & - & 19.52 & 44.45 & - & 38.20 & 70.12 & 97.81 \\
Mean & - & - & - & 9.76 & 17.93 & - & 18.16 & 30.88 & 41.08 \\
Median & - & - & - & 9.76 & 14.85 & - & 15.51 & 31.13 & 37.50 \\
Standard deviation & - & - & - & 4.38 & 10.80 & - & 10.66 & 14.65 & 22.98 \\
\hline Descriptive Statistics & & & Non-Heating Season (Spring/Summer) & & \\
\hline Minimum & 2.81 & 6.18 & - & 0.73 & 4.10 & 4.71 & 3.44 & 2.41 & 5.97 \\
Maximum & 14.07 & 19.75 & - & 11.96 & 22.10 & 24.51 & 11.53 & 14.25 & 32.32 \\
Mean & 7.66 & 10.79 & - & 7.34 & 13.26 & 13.77 & 8.05 & 6.46 & 16.72 \\
Median & 7.55 & 9.90 & - & 12.54 & 12.53 & 14.87 & 8.36 & 5.19 & 16.77 \\
Standard deviation & 2.92 & 3.75 & - & 7.34 & 5.73 & 5.67 & 2.88 & 3.53 & 6.72 \\
\hline
\end{tabular}

Table 2. Descriptive statistics calculated for $\mathrm{PM}_{10}, \mathrm{PM}_{2,5}$ and $\mathrm{PM}_{1.0}$ concentrations for measurement points 6, 7 and 8 located in Poznan. All values in this table are given in $\mu \mathrm{g} / \mathrm{m}^{3}$.

\begin{tabular}{|c|c|c|c|c|}
\hline & \multicolumn{2}{|c|}{ Heating Season (25 October-22 November 2016) } & \multicolumn{2}{|c|}{ Non-Heating Season (05 June-02 July 2017) } \\
\hline \multicolumn{5}{|c|}{$\mathrm{PM}_{10}$} \\
\hline Descriptive Statistics & Jana Pawła II St. & Szymanowskiego St. & Jana Pawła II St. & Szymanowskiego St. \\
\hline Minimum & 9.4 & 8.7 & 5.2 & 1.0 \\
\hline Maximum & 68.6 & 69.6 & 42.8 & 22.6 \\
\hline Mean & 25.4 & 32.9 & 16.6 & 14.7 \\
\hline Median & 21.5 & 34.5 & 15.1 & 15.7 \\
\hline Standard deviation & 14.6 & 15.5 & 8.5 & 5.2 \\
\hline \multicolumn{5}{|c|}{$\mathrm{PM}_{2.5}$} \\
\hline Descriptive Statistics & Jana Pawła II St. & Szymanowskiego St. & Jana Pawła II St. & Szymanowskiego St. \\
\hline Minimum & 2.2 & 7.2 & 1.2 & 7.2 \\
\hline Maximum & 39.9 & 88.5 & 40.3 & 17.1 \\
\hline Mean & 15.2 & 30.8 & 10.4 & 11.0 \\
\hline Median & 12.9 & 27.2 & 8.7 & 10.9 \\
\hline Standard deviation & 10.0 & 19.1 & 9.1 & 2.5 \\
\hline \multicolumn{5}{|c|}{$\mathrm{PM}_{1.0}$} \\
\hline Descriptive Statistics & Jana Pawła II St. & - & Jana Pawła II St. & - \\
\hline Minimum & 2.47 & - & 2.72 & - \\
\hline Maximum & 22.87 & - & 10.35 & - \\
\hline Mean & 8.50 & - & 5.72 & - \\
\hline Median & 7.65 & - & 5.36 & - \\
\hline Standard deviation & 5.27 & - & 1.95 & - \\
\hline
\end{tabular}


Studies carried out in Wrocław and Poznań confirmed that concentrations of all PM fractions are higher in the heating period than in the non-heating period.

\subsection{Analysis of Variability in Concentrations of Elemental/Organic Carbon and Selected Ions}

Table 3 presents values of concentrations of selected anions, cations, OC and EC, along with descriptive statistics in specific measurement series for $\mathrm{PM}_{2.5}$ and $\mathrm{PM}_{10}$ fractions in Wrocław. These studies took place in Wrocław both in the heating and non-heating seasons, and high concentrations of $\mathrm{PO}_{4}{ }^{3-}$ and $\mathrm{SO}_{4}{ }^{2}$ ions were measured. In the heating season for Series 4 and in the non-heating season for Series 5 , the average concentration of total carbon (TC) (TC = EC + OC) was respectively equal to $4.90 \mu \mathrm{g} / \mathrm{m}^{3}$ and $1.53 \mu \mathrm{g} / \mathrm{m}^{3}$. The highest values of organic carbon in $\mathrm{PM}_{2.5}$ were measured in Series 4 (winter 2016) and the value was equal to $17.13 \mu \mathrm{g} / \mathrm{m}^{3}$. For the 2016 winter season, the average concentration of OC was equal to $7.96 \mu \mathrm{g} / \mathrm{m}^{3}$, with daily average concentrations values contained in the range of $2.00 \mu \mathrm{g} / \mathrm{m}^{3}$ to $17.13 \mu \mathrm{g} / \mathrm{m}^{3}$. The concentration of EC was lower than the content of OC in all measurement series carried out in Wrocław at Kosiby Street. The highest average value of EC for the winter period in 2016 (Series 4) was equal to $1.83 \mu \mathrm{g} / \mathrm{m}^{3}$, and the daily average concentrations ranged from $0.46 \mu \mathrm{g} / \mathrm{m}^{3}$ to $4.06 \mu \mathrm{g} / \mathrm{m}^{3}$. Analysis of the composition of $\mathrm{PM}_{2.5}$ in Wroclaw in the winter season of 2015 revealed that among the determined cations, dominating concentrations were observed for $\mathrm{NH}_{4}{ }^{+}\left(2.20 \mu \mathrm{g} / \mathrm{m}^{3}\right)$ and $\mathrm{Na}^{+}\left(1.14 \mu \mathrm{g} / \mathrm{m}^{3}\right)$. The daily average concentration of $\mathrm{NH}_{4}{ }^{+}$in atmospheric air ranged from $0.30 \mu \mathrm{g} / \mathrm{m}^{3}$ to $5.29 \mu \mathrm{g} / \mathrm{m}^{3}$. The daily average concentration of $\mathrm{Na}^{+}$ranged from $0.64 \mu \mathrm{g} / \mathrm{m}^{3}$ to $8.12 \mu \mathrm{g} / \mathrm{m}^{3}$. Among the determined anions, for the winter season, a dominating concentration was noted for $\mathrm{SO}_{4}{ }^{2-}, \mathrm{NO}_{3}{ }^{-}$and $\mathrm{Cl}^{-}$. Sulfate anion content in the samples ranged from $4.75 \mu \mathrm{g} / \mathrm{m}^{3}$ to $11.34 \mu \mathrm{g} / \mathrm{m}^{3}$. The range of concentrations of $\mathrm{NO}_{3}{ }^{-}$in the air was from $1.14 \mu \mathrm{g} / \mathrm{m}^{3}$ to $18.56 \mu \mathrm{g} / \mathrm{m}^{3}$. Concentrations of $\mathrm{Cl}^{-}$ions ranged from $0.57 \mu \mathrm{g} / \mathrm{m}^{3}$ to $10.51 \mu \mathrm{g} / \mathrm{m}^{3}$. The concentration of OC determined in $\mathrm{PM}_{2.5}$ at the station at Kosiby Street ranged between $1.22 \mu \mathrm{g} / \mathrm{m}^{3}$ and $16.48 \mu \mathrm{g} / \mathrm{m}^{3}$, with the average value for measurement period at the level of $5.79 \mu \mathrm{g} / \mathrm{m}^{3}$. In the summer season, the dominating percentage in the total weight of ions determined in PM during Series 3 was $\mathrm{SO}_{4}{ }^{2-}\left(2.28 \mu \mathrm{g} / \mathrm{m}^{3}\right), \mathrm{NO}_{3}{ }^{-}$ $(0.69 \mu \mathrm{g} / \mathrm{m}), \mathrm{NH}_{4}{ }^{+}\left(2.44 \mu \mathrm{g} / \mathrm{m}^{3}\right)$ and $\mathrm{Ca}^{2+}\left(2.25 \mu \mathrm{g} / \mathrm{m}^{3}\right)$. In the case of EC and $\mathrm{OC}$, the maximum daily concentration was respectively at the level of $0.63 \mu \mathrm{g} / \mathrm{m}^{3}$ (Series 1) and $4.26 \mu \mathrm{g} / \mathrm{m}^{3}$ (Series 3). In the non-heating season, the higher content of $\mathrm{NO}_{3}{ }^{-}, \mathrm{SO}_{4}{ }^{2-}$ and also OC and EC in the composition of $\mathrm{PM}_{2.5}$ may indicate an influence of fuel combustion on the composition of particulate matter and, moreover, the higher content of $\mathrm{Na}^{+}$and $\mathrm{Cl}^{-}$ions may indicate the influence of salt spread on roads in the winter season $[12,44,45]$.

Table 3. Concentrations of $\mathrm{PM}_{2.5}$-bound anions, cations, organic carbon (OC) and elemental carbon (EC) at the selected measuring stations. All values in this table are given in $\mu \mathrm{g} / \mathrm{m}^{3}$.

\begin{tabular}{|c|c|c|c|c|c|c|c|c|c|c|c|c|}
\hline & $\mathbf{F}^{-}$ & $\mathrm{Cl}^{-}$ & $\mathrm{NO}_{3}{ }^{-}$ & $\mathrm{PO}_{4}^{3-}$ & $\mathrm{SO}_{4}^{2-}$ & $\mathrm{Na}^{+}$ & $\mathrm{NH}_{4}{ }^{+}$ & $\mathbf{K}^{+}$ & $\mathrm{Mg}^{2+}$ & $\mathrm{Ca}^{2+}$ & OC & EC \\
\hline \multicolumn{13}{|c|}{ Wrocław, Kosiby St. Series 1 (26 June-26 July 2014; Summer 2014) } \\
\hline No. of samples & 27 & 27 & 27 & 27 & 27 & 27 & 27 & 27 & 27 & 27 & 27 & 27 \\
\hline Mean & 0.06 & 0.13 & 0.32 & 0.04 & 1.42 & 0.18 & 0.35 & 0.07 & 0.00 & 0.04 & 3.23 & 0.63 \\
\hline Minimum & $<\mathrm{dl}$ & 0.08 & 0.13 & $<\mathrm{dl}$ & 0.66 & 0.05 & 0.15 & $<\mathrm{dl}$ & $<\mathrm{dl}$ & $<\mathrm{dl}$ & 2.12 & $<\mathrm{dl}$ \\
\hline Maximum & 0.19 & 0.449 & 2.47 & 0.35 & 3.08 & 0.86 & 0.80 & 0.66 & 0.00 & 0.21 & 4.97 & 1.64 \\
\hline Median & 0.05 & 0.10 & 0.17 & 0.00 & 1.24 & 0.08 & 0.34 & 0.00 & 0.00 & 0.00 & 3.07 & 0.59 \\
\hline Standard deviation & 0.04 & 0.08 & 0.45 & 0.11 & 0.65 & 0.21 & 0.17 & 0.18 & 0.00 & 0.19 & 0.74 & 0.34 \\
\hline \multicolumn{13}{|c|}{ Wrocław, Kosiby St. Series 2 (7 January-7 February 2015; Winter 2015) } \\
\hline No. of samples & 32 & 32 & 32 & 32 & 32 & 32 & 32 & 32 & 32 & 32 & 32 & 32 \\
\hline Mean & 0.13 & 1.76 & 4.20 & 0.07 & 7.77 & 1.14 & 2.20 & 0.19 & 0.06 & 0.02 & 5.79 & 1.42 \\
\hline Minimum & 0.05 & 0.57 & 1.14 & $<\mathrm{dl}$ & 4.75 & 0.64 & 0.30 & $<\mathrm{dl}$ & $<\mathrm{dl}$ & $<\mathrm{dl}$ & 1.22 & 0.45 \\
\hline Maximum & 1.36 & 10.51 & 8.56 & 1.48 & 11.34 & 8.12 & 5.29 & 0.43 & 2.00 & 0.37 & 16.48 & 2.77 \\
\hline Median & 0.09 & 1.34 & 3.87 & 0.00 & 6.91 & 0.80 & 1.66 & 0.09 & 0.00 & 0.00 & 4.73 & 1.19 \\
\hline Standard deviation & 0.23 & 1.84 & 2.46 & 0.27 & 2.06 & 1.31 & 1.62 & 0.41 & 0.07 & 0.35 & 3.69 & 0.67 \\
\hline
\end{tabular}


Table 3. Cont.

\begin{tabular}{|c|c|c|c|c|c|c|c|c|c|c|c|c|}
\hline & $\mathbf{F}^{-}$ & $\mathrm{Cl}^{-}$ & $\mathrm{NO}_{3}{ }^{-}$ & $\mathrm{PO}_{4}^{3-}$ & $\mathrm{SO}_{4}{ }^{2-}$ & $\mathrm{Na}^{+}$ & $\mathrm{NH}_{4}^{+}$ & $\mathrm{K}^{+}$ & $\mathrm{Mg}^{2+}$ & $\mathrm{Ca}^{2+}$ & OC & EC \\
\hline \multicolumn{13}{|c|}{ Wrocław, Kosiby St. Series 3 (31 July-13 August 2015; Summer 2015) } \\
\hline No. of samples & 14 & 14 & 14 & 14 & 14 & 14 & 14 & 14 & 14 & 14 & 14 & 14 \\
\hline Mean & 0.08 & 0.39 & 0.69 & 0.03 & 5.28 & 0.39 & 2.44 & 0.36 & 0.15 & 2.25 & 4.26 & 0.62 \\
\hline Minimum & 0.05 & 0.10 & 0.30 & 0.02 & 1.76 & 0.13 & 0.59 & 0.16 & 0.09 & 0.50 & 2.76 & $<\mathrm{dl}$ \\
\hline Maximum & 0.17 & 1.56 & 1.30 & 0.05 & 9.42 & 1.32 & 4.54 & 0.78 & 0.38 & 7.93 & 6.47 & 1.12 \\
\hline Median & 0.08 & 0.26 & 0.63 & 0.03 & 5.30 & 0.28 & 2.51 & 0.30 & 0.12 & 1.08 & 4.33 & 0.62 \\
\hline Standard deviation & 0.03 & 0.39 & 0.24 & 0.01 & 2.17 & 0.31 & 1.04 & 0.17 & 0.09 & 2.37 & 0.97 & 0.25 \\
\hline \multicolumn{13}{|c|}{ Wrocław, Kosiby St. Series 4 (9-26 January 2016; Winter 2016) } \\
\hline No. of samples & 18 & 18 & 18 & 18 & 18 & 18 & 18 & 18 & 18 & 18 & 18 & 18 \\
\hline Mean & 0.05 & 2.97 & 1.01 & 0.07 & 4.07 & 0.74 & 4.16 & 0.56 & 0.16 & 1.02 & 7.96 & 1.83 \\
\hline Minimum & 0.02 & 1.52 & 0.03 & $<\mathrm{dl}$ & 2.24 & 0.31 & 0.02 & 0.28 & 0.09 & 0.51 & 2.00 & 0.46 \\
\hline Maximum & 0.18 & 5.80 & 2.00 & 0.51 & 6.33 & 2.20 & 9.40 & 1.24 & 0.35 & 3.13 & 17.13 & 4.06 \\
\hline Median & 0.08 & 0.48 & 1.08 & 0.00 & 4.09 & 0.50 & 4.84 & 0.44 & 0.14 & 0.76 & 7.97 & 1.61 \\
\hline Standard deviation & 0.04 & 1.13 & 0.48 & 0.16 & 1.13 & 0.57 & 2.81 & 0.30 & 0.07 & 0.63 & 3.69 & 0.82 \\
\hline \multicolumn{13}{|c|}{ Wrocław, Kosiby St. Series 5 (9-23 May 2016; Spring 2016) } \\
\hline No. of samples & 15 & 15 & 15 & 15 & 15 & 15 & 15 & 15 & 15 & 15 & 15 & 15 \\
\hline Mean & 0.03 & 1.27 & 0.15 & 0.19 & 2.67 & 0.55 & 1.08 & 0.15 & 0.05 & 0.88 & 2.70 & 0.36 \\
\hline Minimum & 0.02 & 1.16 & 0.02 & $<\mathrm{dl}$ & 1.76 & 0.20 & $<\mathrm{dl}$ & 0.07 & 0.03 & 0.23 & 1.41 & 0.12 \\
\hline Maximum & 0.05 & 1.51 & 0.58 & 0.54 & 4.04 & 1.06 & 3.11 & 0.21 & 0.13 & 7.45 & 3.98 & 0.80 \\
\hline Median & 0.03 & 1.25 & 0.08 & 0.04 & 2.56 & 0.47 & 0.96 & 0.15 & 0.04 & 0.33 & 2.75 & 0.35 \\
\hline Standard deviation & 0.01 & 0.10 & 0.18 & 0.21 & 0.67 & 0.23 & 0.91 & 0.04 & 0.02 & 1.83 & 0.73 & 0.18 \\
\hline \multicolumn{13}{|c|}{ Poznań, Jana Pawła II St. (25 October-22 November 2016; Autumn 2016) } \\
\hline No. of samples & 28 & 28 & 28 & 28 & 28 & 28 & 28 & 28 & 28 & 28 & 28 & 28 \\
\hline Mean & 1.988 & 0.689 & 0.638 & 0.630 & 0.889 & 0.619 & 0.047 & 0.077 & 0.044 & 0.236 & 8.36 & 2.53 \\
\hline Minimum & 10.508 & 4.201 & 8.607 & 1.092 & 6.043 & 2.896 & 1.809 & 0.586 & 0.289 & 6.485 & 2.35 & 0.83 \\
\hline Maximum & 3.088 & 1.160 & 2.632 & 0.784 & 2.107 & 0.886 & 0.553 & 0.159 & 0.068 & 0.730 & 26.66 & 6.64 \\
\hline Median & 2.741 & 0.929 & 2.162 & 0.752 & 1.832 & 0.768 & 0.465 & 0.131 & 0.056 & 0.416 & 7.14 & 2.32 \\
\hline Standard deviation & 1.657 & 0.683 & 1.893 & 0.105 & 1.098 & 0.418 & 0.453 & 0.097 & 0.046 & 1.177 & 5.16 & 1.39 \\
\hline \multicolumn{13}{|c|}{ Polanka St. (25 October-22 November 2016; Autumn 2016) } \\
\hline No. of samples & 28 & 28 & 28 & 28 & 28 & 28 & 28 & 28 & 28 & 28 & 28 & 28 \\
\hline Mean & 0.757 & 0.383 & 0.870 & 0.378 & 0.940 & 0.451 & 0.050 & 0.049 & 0.025 & 0.122 & 14.77 & 3.26 \\
\hline Minimum & 6.317 & 3.858 & 21.816 & 0.951 & 7.939 & 1.053 & 2.540 & 0.528 & 0.439 & 0.384 & 2.91 & 1.14 \\
\hline Maximum & 2.287 & 1.154 & 5.801 & 0.533 & 3.506 & 0.612 & 1.102 & 0.215 & 0.049 & 0.197 & 43.21 & 6.22 \\
\hline Median & 1.882 & 0.753 & 4.802 & 0.430 & 3.314 & 0.562 & 1.107 & 0.188 & 0.033 & 0.172 & 12.07 & 2.84 \\
\hline Standard deviation & 1.172 & 0.859 & 4.701 & 0.209 & 1.822 & 0.130 & 0.637 & 0.126 & 0.074 & 0.070 & 10.59 & 1.46 \\
\hline \multicolumn{13}{|c|}{ Jana Pawła II St. (5 June-2 July 2017; Summer 2017) } \\
\hline No. of samples & 28 & 28 & 28 & 28 & 28 & 28 & 28 & 28 & 28 & 28 & 28 & 28 \\
\hline Mean & 0.010 & 0.123 & 0.150 & 0.328 & 0.290 & 0.465 & 0.008 & 0.020 & 0.052 & 0.076 & 3.61 & 0.63 \\
\hline Minimum & 0.155 & 0.563 & 1.384 & 4.592 & 2.202 & 2.370 & 0.046 & 0.082 & 0.477 & 5.325 & 0.82 & 0.12 \\
\hline Maximum & 0.048 & 0.442 & 0.713 & 2.348 & 1.353 & 2.029 & 0.016 & 0.048 & 0.242 & 2.524 & 5.07 & 1.22 \\
\hline Median & 0.029 & 0.453 & 0.693 & 1.791 & 1.400 & 2.078 & 0.011 & 0.048 & 0.257 & 2.611 & 3.58 & 0.57 \\
\hline Standard deviation & 0.041 & 0.098 & 0.232 & 1.122 & 0.406 & 0.333 & 0.011 & 0.014 & 0.105 & 1.492 & 0.83 & 0.34 \\
\hline \multicolumn{13}{|c|}{ Polanka St. (5 June-2 July 2017; Summer 2017) } \\
\hline No. of samples & 28 & 28 & 28 & 28 & 28 & 28 & 28 & 28 & 28 & 28 & 28 & 28 \\
\hline Mean & 0.004 & 0.133 & 0.228 & 0.363 & 0.86 & 0.465 & 0.008 & 0.020 & 0.052 & 0.076 & 3.88 & 0.81 \\
\hline Minimum & 0.130 & 0.382 & 1.845 & 2.668 & 3.704 & 2.221 & 0.093 & 0.069 & 0.108 & 1.709 & 2.60 & 0.45 \\
\hline Maximum & 0.045 & 0.199 & 0.618 & 0.992 & 1.679 & 1.098 & 0.036 & 0.040 & 0.081 & 0.611 & 5.75 & 1.60 \\
\hline Median & 0.046 & 0.177 & 0.389 & 0.506 & 1.652 & 0.622 & 0.034 & 0.039 & 0.081 & 0.413 & 3.86 & 0.71 \\
\hline Standard deviation & 0.033 & 0.063 & 0.431 & 0.797 & 0.551 & 0.758 & 0.017 & 0.011 & 0.015 & 0.476 & 0.85 & 0.28 \\
\hline
\end{tabular}

The analysis of the composition of $\mathrm{PM}_{2.5}$ in Poznan in the fall-winter season revealed that among the determined cations, the dominating percentage belonged to (Table 3): $\mathrm{Na}^{+}$(at both stations), $\mathrm{NH}_{4}{ }^{+}$ (Polanka-Station 7), and Ca ${ }^{2+}$ (Jana Pawła II Street-Station 8) ions. Concentrations of $\mathrm{Na}^{+}$in the samples originating from the Polanka Street station ranged from $0.451 \mu \mathrm{g} / \mathrm{m}^{3}$ to $1.053 \mu \mathrm{g} / \mathrm{m}^{3}$ and in 
samples from Jana Pawła II Street station, concentrations ranged from $0.619 \mu \mathrm{g} / \mathrm{m}^{3}$ to $2.896 \mu \mathrm{g} / \mathrm{m}^{3}$. The concentration of $\mathrm{NH}_{4}{ }^{+}$in samples collected at the station at Polanka Street was twice as high as in samples collected at the second station and range from $0.050 \mu \mathrm{g} / \mathrm{m}^{3}$ to $2.540 \mu \mathrm{g} / \mathrm{m}^{3}$ with an average value of $1.102 \mu \mathrm{g} / \mathrm{m}^{3}$. Furthermore, in the samples collected at the station at Jana Pawła II Street (Station 8) a three-fold higher concentration of $\mathrm{Ca}^{2+}$ (average: $0.730 \mu \mathrm{g} / \mathrm{m}^{3}$ ) was observed in relation to the concentration measured at the station at Polanka Street $\left(0.197 \mu \mathrm{g} / \mathrm{m}^{3}\right)$. Among the determined anions, the dominating percentage belonged to $\mathrm{SO}_{4}{ }^{2-}, \mathrm{NH}_{3}{ }^{-}$and $\mathrm{F}^{-}$ions. The content of sulfate anions in samples taken at the stations at Polanka Street ranged from $0.940 \mu \mathrm{g} / \mathrm{m}^{3}$ to $7.939 \mu \mathrm{g} / \mathrm{m}^{3}$ and in samples collected at Jana Pawła II station, the content ranged from $0.889 \mu \mathrm{g} / \mathrm{m}^{3}$ to $6.043 \mu \mathrm{g} / \mathrm{m}^{3}$. The percentage of $\mathrm{NO}_{3}{ }^{-}$in the samples was relatively high and equal to $0.870-21.816 \mu \mathrm{g} / \mathrm{m}^{3}$ in the samples from Polanka Street station (Station 7) and 0.638-8.607 $\mu \mathrm{g} / \mathrm{m}^{3}$ from Jana Pawła II Street station (Station 8). The concentrations of $\mathrm{F}^{-}$ions ranged from $0.757-6.317 \mu \mathrm{g} / \mathrm{in}$ samples collected at Polanka Street and 1.988-10.508 $\mu \mathrm{g} / \mathrm{m}^{3}$ in samples collected at the Jana Pawła II Street station. The determined range of concentrations of nitrate in samples collected at both measurement stations is similar to concentrations determined for other locations in Poland, which could indicate its high percentage in the general background of the country. Values of concentrations of sulfate anions at Polanka Street are similar to concentrations determined in the air of Katowice, and at the same time, higher than in other regions in the country (Gdańsk, Puszcza Borecka) [46,47]. It may be assumed that the air quality in Poznan is affected by the same factors as in south of the country; i.e., primarily combustion of hard and brown coal. The daily average concentrations of OC determined in $\mathrm{PM}_{2.5}$ at the station at Polanka Street ranged from $2.91 \mu \mathrm{g} / \mathrm{m}^{3}$ to $37.94 \mu \mathrm{g} / \mathrm{m}^{3}$ with an average value for the measurement period equal to $13.52 \mu \mathrm{g} / \mathrm{m}^{3}$. In the case of the station located at Jana Pawła II Street, the concentrations of OC ranged from $2.35 \mu \mathrm{g} / \mathrm{m}^{3}$ to $26.66 \mu \mathrm{g} / \mathrm{m}^{3}$ with an average value equal to $8.36 \mu \mathrm{g} / \mathrm{m}^{3}$. The concentrations of EC in the air were lower than the concentrations of OC and ranged respectively from $1.14 \mu \mathrm{g} / \mathrm{m}^{3}$ to $6.22 \mu \mathrm{g} / \mathrm{m}^{3}$ for $\mathrm{PM}_{2.5}$ measured at station at Polanka Street and $0.83-6.64 \mu \mathrm{g} / \mathrm{m}^{3}$ for $\mathrm{PM}_{2.5}$ at the station at Jana Pawła II Street. In the summer season, the concentrations of all analyzed ions at both stations were at a very similar level; however, they were much lower in comparison to the fall-winter season for most of the ions. The dominating percentage in the sum of ions determined in PM in the summer season belonged to $\mathrm{PO}_{4}{ }^{3-}\left(0.328 \mu \mathrm{g} / \mathrm{m}^{3}\right.$ at the station at Jana Pawła II Street and $0.363 \mu \mathrm{g} / \mathrm{m}^{3}$ at the station at Polanka Street), $\mathrm{SO}_{4}{ }^{2-}\left(0.290 \mu \mathrm{g} / \mathrm{m}^{3}\right.$ at the station at Jana Pawła II Street and $0.86 \mu \mathrm{g} / \mathrm{m}^{3}$ at the station at Polanka Street) and $\mathrm{Na}^{+}\left(0.465 \mu \mathrm{g} / \mathrm{m}^{3}\right.$ at both of the stations). At the station at Polanka Street, the concentrations of $\mathrm{F}^{-}(99 \%), \mathrm{Cl}^{-}(63 \%), \mathrm{NO}_{3}{ }^{-}(74 \%)$ and $\mathrm{K}^{+}(84 \%)$ and $\mathrm{Ca}^{2+}(80 \%)$ determined in $\mathrm{PM}_{2.5}$ particulate matter in the summer season were lower than in the winter season. Furthermore, concentrations of $\mathrm{Mg}^{2+}$ bound to $\mathrm{PM}_{2.5}$ in the air at the station at Polanka Street, were twice as high than in the summer season. In the case of the station at Jana Pawła II Street, the concentration of ions bound with $\mathrm{PM}_{2.5}$ in the summer season was lower than in the winter season. For $\mathrm{F}^{-}$, these concentrations were lower than $99 \%,\left(\mathrm{Cl}^{-}=81 \% ; \mathrm{NO}_{3}{ }^{-}=64 \% ; \mathrm{PO}_{4}{ }^{3-}=43 \% ; \mathrm{SO}_{4}{ }^{2-}=68 \% ; \mathrm{Na}^{+}=25 \%\right.$; $\mathrm{NH}_{4}{ }^{+}=83 \% ; \mathrm{K}^{+}=97 \% ; \mathrm{Mg}^{2+}=89 \%$ and $\mathrm{Ca}^{2+}=68 \%$ ). A lower content of $\mathrm{PO}_{4}{ }^{3-}, \mathrm{SO}_{4}{ }^{2-}$ and $\mathrm{NH}_{4}{ }^{+}$ ions in the sum of the ions determined in $\mathrm{PM}_{2.5}$ in the non-heating season may indicate the influence of fossil fuel and biomass combustion on the composition of particulate matter. $\mathrm{Cl}^{-}$and $\mathrm{Na}^{+}$ions may indicate the influence of salting and sanding in the winter season $[12,44,45]$. The content of OC and $\mathrm{EC}$ in $\mathrm{PM}_{2.5}$ particulate matter at both of the stations in the summer season were at a similar level, however it was about four times lower than the content in the winter season. Higher concentrations of OC, EC and selected ions during the heating period are also observed in other Polish and European cities (Table 4). 
Table 4. Concentrations of $\mathrm{PM}_{2.5}$ and its main chemical constituents $\left(\mu \mathrm{g} / \mathrm{m}^{3}\right)$ recorded at selected stations in Europe.

\begin{tabular}{|c|c|c|c|c|c|c|c|c|c|c|c|c|c|c|}
\hline \multirow{2}{*}{ Location } & \multirow{2}{*}{ Period } & \multirow[b]{2}{*}{$\mathbf{P M}_{2.5}$} & \multicolumn{12}{|c|}{ Concentration } \\
\hline & & & $\mathbf{F}^{-}$ & $\mathrm{Cl}^{-}$ & $\mathrm{NO}_{3}^{-}$ & $\mathrm{PO}_{4}{ }^{3-}$ & $\mathrm{SO}_{4}{ }^{2-}$ & $\mathrm{Na}^{+}$ & $\mathrm{NH}_{4}{ }^{+}$ & $\mathrm{K}^{+}$ & $\mathrm{Mg}^{2+}$ & $\mathrm{Ca}^{2+}$ & OC & EC \\
\hline \multirow{5}{*}{$\begin{array}{l}\text { Wroclaw (PL), } \\
\text { Kosiby Street, B }\end{array}$} & NH 26 June-26 July 2014 & 10.79 & 0.06 & 0.13 & 0.32 & 0.04 & 1.42 & 0.18 & 0.35 & 0.07 & 0.00 & 0.04 & 3.23 & 0.63 \\
\hline & H 7 January-7 February 2015 & 17.93 & 0.13 & 1.76 & 4.20 & 0.07 & 7.77 & 1.14 & 2.20 & 0.19 & 0.06 & 0.02 & 5.79 & 1.42 \\
\hline & NH 31 July-13 August 2015 & 13.26 & 0.08 & 0.39 & 0.69 & 0.03 & 5.28 & 0.39 & 2.44 & 0.36 & 0.15 & 2.25 & 4.26 & 0.62 \\
\hline & H 9-26 January 2016 & 41.08 & 0.05 & 2.97 & 1.01 & 0.07 & 4.07 & 0.74 & 4.16 & 0.56 & 0.16 & 1.02 & 7.96 & 1.83 \\
\hline & NH 9-23 May 2016 & 6.46 & 0.03 & 1.27 & 0.15 & 0.19 & 2.67 & 0.55 & 1.08 & 0.15 & 0.05 & 0.88 & 2.70 & 0.36 \\
\hline \multirow{2}{*}{$\begin{array}{c}\text { Poznan (PL), } \\
\text { Polanka Street, B }\end{array}$} & H 25 October-22 November 2016 & 30.80 & 0.757 & 0.383 & 0.870 & 0.378 & 0.940 & 0.451 & 0.050 & 0.049 & 0.025 & 0.122 & 14.77 & 3.26 \\
\hline & NH 5 June-2 July 2017 & 11.00 & 0.004 & 0.133 & 0.228 & 0.363 & 0.86 & 0.465 & 0.008 & 0.020 & 0.052 & 0.076 & 3.88 & 0.81 \\
\hline \multirow{3}{*}{ Racibórz (PL), C [39] } & 2011,2012 & 31.56 & - & 1.35 & 3.06 & - & 3.64 & 0.28 & 1.66 & 1.35 & 0.03 & 0.04 & 12.08 & 1.96 \\
\hline & H 2011, 2012 & 55.36 & - & 3.01 & 5.50 & - & 5.36 & 0.49 & 3.31 & 0.25 & 0.03 & 0.05 & 22.54 & 3.59 \\
\hline & NH 2011, 2012 & 14.76 & - & 0.18 & 1.34 & - & 2.43 & 0.12 & 0.50 & 0.02 & 0.03 & 0.04 & 4.70 & 0.80 \\
\hline \multirow{3}{*}{$\begin{array}{c}\text { Puszcza Borecka (PL), } \\
\text { B [48] }\end{array}$} & 2011 & 12.79 & - & 0.14 & 1.43 & - & 2.11 & 0.30 & 0.78 & 0.11 & 0.02 & 0.08 & 3.42 & 0.58 \\
\hline & H 2011 & 16.49 & - & 0.15 & 2.89 & - & 2.69 & 0.56 & 1.16 & 0.18 & 0.02 & 0.08 & 4.41 & 0.84 \\
\hline & NH 2011 & 9.79 & - & 0.04 & 0.37 & - & 1.69 & 0.10 & 0.50 & 0.06 & 0.02 & 0.08 & 2.62 & 0.36 \\
\hline \multirow{3}{*}{ Zielonka (PL), A [48] } & 2011 & 16.07 & - & 0.14 & 1.46 & - & 1.78 & 0.12 & 1.08 & 0.10 & 0.01 & 0.10 & 4.25 & 0.88 \\
\hline & H 2011 & 20.49 & - & 0.23 & 2.47 & - & 2.15 & 0.13 & 1.66 & 0.15 & 0.01 & 0.08 & 5.59 & 1.25 \\
\hline & NH 2011 & 11.97 & - & 0.05 & 0.54 & - & 1.44 & 0.11 & 0.54 & 0.06 & 0.01 & 0.12 & 3.02 & 0.53 \\
\hline \multirow{3}{*}{ Košetice (CZ), B [49] } & February 2009-April 2010 & 15.7 & - & 0.04 & 2.20 & - & 2.85 & 0.04 & 1.52 & 0.09 & $<0.01$ & - & 4.07 & 0.61 \\
\hline & February 2009-April 2010 & 22.5 & - & 0.05 & 2.83 & - & 3.86 & 0.04 & 1.92 & 0.15 & $<0.01$ & - & 6.00 & 0.80 \\
\hline & February 2009-April 2010 & 9.7 & - & 0.01 & 0.55 & - & 2.30 & 0.03 & 0.96 & 0.03 & $<0.01$ & - & 2.12 & 0.36 \\
\hline \multirow{3}{*}{ Üto (FI), B [50] } & 2011 & 6.55 & - & 0.05 & 0.28 & - & 0.33 & 0.28 & 0.24 & 0.23 & 0.22 & 0.02 & - & - \\
\hline & Н 2011 & 6.58 & - & 0.05 & 0.12 & - & 0.37 & 0.35 & 0.29 & 0.05 & 0.04 & 0.02 & - & - \\
\hline & NH 2011 & 6.53 & - & 0.06 & 0.44 & - & 0.30 & 0.20 & 0.19 & 0.41 & 0.41 & 0.02 & - & - \\
\hline \multirow{3}{*}{ Neuglobsow (DE), B [48] } & 2012 & 10.31 & - & 0.13 & 2.06 & - & 1.95 & 0.17 & 1.24 & 0.09 & 0.02 & 0.03 & 2.52 & 0.32 \\
\hline & Н 2012 & 13.14 & - & 0.21 & 3.59 & - & 2.11 & 0.22 & 1.71 & 0.12 & 0.02 & 0.03 & 3.02 & 0.45 \\
\hline & NH 2012 & 7.47 & - & 0.06 & 0.53 & - & 1.79 & 0.12 & 0.76 & 0.05 & 0.01 & 0.02 & 2.05 & 0.20 \\
\hline \multirow{3}{*}{$\begin{array}{c}\text { Cabauw-Zijdeweg (NL), } \\
\text { A [48] }\end{array}$} & 2011 & 15.25 & - & 0.20 & 3.93 & - & 2.27 & 0.25 & 1.69 & 0.10 & 0.04 & 0.06 & 2.30 & 0.56 \\
\hline & Н 2011 & 18.56 & - & 0.31 & 4.91 & - & 2.59 & 0.26 & 2.07 & 0.14 & 0.04 & 0.06 & 2.83 & 0.72 \\
\hline & NH 2011 & 11.97 & - & 0.08 & 2.88 & - & 1.92 & 0.25 & 1.28 & 0.07 & 0.04 & 0.06 & 1.75 & 0.39 \\
\hline \multirow{3}{*}{ Iskrba (Sl), B [50] } & 2010 & 11.61 & - & 0.04 & 0.08 & - & 0.88 & 0.04 & 0.82 & 0.12 & 0.02 & 0.07 & 3.38 & 0.38 \\
\hline & Н 2010 & 13.22 & - & 0.05 & 0.12 & - & 0.91 & 0.05 & 0.85 & 0.17 & 0.02 & 0.08 & 3.77 & 0.53 \\
\hline & NH 2010 & 10.07 & - & 0.03 & 0.04 & - & 0.85 & 0.04 & 0.79 & 0.08 & 0.02 & 0.06 & 2.99 & 0.23 \\
\hline
\end{tabular}


Table 4. Cont

\begin{tabular}{|c|c|c|c|c|c|c|c|c|c|c|c|c|c|c|}
\hline \multirow{2}{*}{ Location } & \multirow{2}{*}{ Period } & \multirow[b]{2}{*}{$\mathbf{P M}_{2.5}$} & \multicolumn{12}{|c|}{ Concentration } \\
\hline & & & $\mathbf{F}^{-}$ & $\mathrm{Cl}^{-}$ & $\mathrm{NO}_{3}^{-}$ & $\mathrm{PO}_{4}{ }^{3-}$ & $\mathrm{SO}_{4}^{2-}$ & $\mathrm{Na}^{+}$ & $\mathrm{NH}_{4}^{+}$ & $\mathrm{K}^{+}$ & $\mathrm{Mg}^{2+}$ & $\mathrm{Ca}^{2+}$ & OC & EC \\
\hline \multirow{3}{*}{ Ispra (IT), B [48] } & 2010 & 17.92 & - & 0.55 & 0.83 & - & 0.75 & 0.11 & 1.39 & 0.33 & 0.002 & 0.06 & 5.88 & 1.27 \\
\hline & H 2010 & 26.52 & - & 0.32 & 1.41 & - & 0.71 & 0.10 & 1.96 & 0.59 & 0.02 & 0.01 & 9.03 & 1.91 \\
\hline & NH 2010 & 9.02 & - & 0.79 & 0.17 & - & 0.78 & 0.11 & 0.84 & 0.07 & 0.03 & 0.10 & 2.71 & 0.65 \\
\hline \multirow{2}{*}{ Katowice (PL), U [39] } & H 2010 & 63.04 & - & 2.63 & 4.06 & - & 5.38 & 0.92 & 3.27 & 0.27 & 0.06 & 0.27 & 7.91 & 13.57 \\
\hline & NH 2010 & 22.73 & - & 0.81 & 1.13 & - & 3.78 & 1.46 & 1.59 & 0.20 & 0.12 & 0.45 & 3.32 & 4.47 \\
\hline \multirow{2}{*}{$\begin{array}{c}\text { Poznan (PL), Jana Pawla II } \\
\text { Street, U }\end{array}$} & H 25 October-22 November 2016 & 15.20 & 1.988 & 0.689 & 0.638 & 0.630 & 0.889 & 0.619 & 0.047 & 0.077 & 0.044 & 0.236 & 8.36 & 2.53 \\
\hline & NH 5 June-2 July 2017 & 10.40 & 0.010 & 0.123 & 0.150 & 0.328 & 0.290 & 0.465 & 0.008 & 0.020 & 0.052 & 0.076 & 3.61 & 0.63 \\
\hline \multirow{2}{*}{ Zabrze (PL), U [51] } & January-March 2009 & 66.85 & - & 1.53 & 3.12 & - & 5.38 & 0.45 & 2.01 & 0.4 & 0.14 & 0.47 & 9.9 & 19.34 \\
\hline & July-November 2009 & 18.44 & - & 0.04 & 0.51 & - & 3.78 & 0.24 & 0.53 & 0.14 & - & - & 4.21 & 4.12 \\
\hline \multirow{2}{*}{ Helsinki (FI), U [52] } & November 2009-February 2010 & - & - & 0.1 & 2.27 & - & 3.18 & 0.05 & 0.74 & 0.04 & 0.04 & 0.26 & - & - \\
\hline & March-May 2013 & - & - & 0.04 & 1.14 & - & 1.64 & 0.04 & 0.46 & 0.01 & 0.05 & 0.18 & - & - \\
\hline \multirow{2}{*}{ Menen (BE), U [53] } & Winter 2003 & \multirow{2}{*}{17} & - & 0.89 & 5.28 & - & 4.99 & - & 1.88 & 0.25 & 0.03 & 0.07 & - & - \\
\hline & Summer 2003 & & - & 0.25 & 4.17 & - & 3.23 & - & 1.92 & 0.13 & 0.02 & 0.06 & - & - \\
\hline \multirow{2}{*}{ Dunkerque (FR), U [54] } & November-December 2010 & 24.9 & - & 0.58 & 5.71 & - & 2.52 & - & 1.91 & - & - & - & - & 6.2 \\
\hline & March-April 2011 & 33.2 & - & 0.54 & 11.06 & - & 2.85 & - & 2.31 & - & - & - & - & 4.73 \\
\hline \multirow{3}{*}{ Budapest (HU), U [55] } & June 2010-March 2013 & 21 & - & 0.11 & 2.14 & - & 2.84 & 0.22 & 1.33 & 0.18 & 0.05 & 0.16 & 5.42 & 2.02 \\
\hline & Winter: June 2010-March 2013 & 28.7 & - & 0.2 & 3.9 & - & 2.54 & 0.3 & 1.8 & 0.3 & 0.04 & 0.12 & 8.23 & 2 \\
\hline & Summer: June 2010-March 2013 & 14 & - & 0.03 & 0.26 & - & 3 & 0.13 & 0.9 & 0.09 & 0.04 & 0.1 & 2.87 & 1.88 \\
\hline \multirow{3}{*}{ Thessaloniki (GR), U [56] } & April 2011-May 2012 & 37.7 & - & 0.39 & 2.4 & - & 3.96 & 0.29 & 3.8 & 0.14 & 0.07 & 1.43 & 6.62 & 1.29 \\
\hline & H: April 2011-May 2012 & 41.9 & - & 0.37 & 3.07 & - & 3.96 & 0.14 & 4.85 & 0.12 & 0.05 & 1.6 & 8.84 & 1.5 \\
\hline & NH: April 2011-May 2012 & 32.9 & - & 0.4 & 1.61 & - & 3.96 & 0.47 & 2.58 & 0.16 & 0.09 & 1.25 & 4.06 & 1.05 \\
\hline \multirow{2}{*}{ Madrid (ES), U [57] } & January-February 2011 & 13.8 & - & 0.15 & 1.16 & - & 0.61 & 0.17 & 0.48 & 0.05 & 0.01 & 0.1 & 1.2 & 1.53 \\
\hline & June 2009 & 16.6 & - & 0.16 & 0.69 & - & 1.02 & 0.2 & 0.27 & 0.05 & 0.03 & 0.21 & 2.71 & 0.94 \\
\hline
\end{tabular}

Country abbreviations (codes ISO 3166 Country Codes): PL-Poland; CZ-Czech Republic; FI-Finland; DE-Germany; BE-Belgium; NL-Netherlands; FR-France; HU-Hungary; GR-Greece;

IT-Italy; Sl-Slovenia; ES-Spain. Designations of stations: A-rural background station; B-regional background station; U-urban background station. H-heating season (months: January-March and October-December); NH-non-heating season (months: April-September). 


\subsection{Identification of the Sources of Origin of Particulate Matter in Wroctaw and Poznan}

Table 5 and Figure 3 present, respectively, the results of the PCA analysis factors for the $\mathrm{PM}_{2.5}$ fraction and linear dependence of the sum of $\mathrm{PM}_{2.5}$-bound cations vs. the sum of $\mathrm{PM}_{2.5}$-bound anions obtained for the heating and non-heating season and for the two selected cities under study.

Table 5. Main factors and their values extracted during principal component analysis (PCA) for $\mathrm{PM}_{2.5}$ fractions.

\begin{tabular}{|c|c|c|c|c|c|}
\hline Measurement Point & Season/Date & Factor 1 & Factor 2 & Factor 3 & Factor 4 \\
\hline Wroclaw, Kosiby Street & $\begin{array}{c}\text { Spring-Summer } \\
\text { 26 June-26 July } 2014 \\
\text { 31 July-13 August } 2015 \\
\text { 9-23 May } 2016\end{array}$ & $\begin{array}{l}\mathrm{SO}_{4}^{2-}(0.93) \\
\mathrm{NH}_{4}^{+}(0.92) \\
\mathrm{Mg}^{2+}(0.83)\end{array}$ & $\begin{array}{l}\mathrm{Cl}^{-}(0.82) \\
\mathrm{Na}^{+}(0.85)\end{array}$ & $\begin{array}{c}\mathrm{F}^{-}(0.86) \\
\mathrm{NO}_{3}^{-}(0.80)\end{array}$ & - \\
\hline Wroclaw, Kosiby Street & $\begin{array}{c}\text { Winter } \\
\text { 7 January-7 February } 2015 \\
\text { 9-26. January } 2016\end{array}$ & $\begin{array}{c}\mathrm{F}^{-}(0.95) \\
\mathrm{Cl}^{-}(0.83) \\
\mathrm{Na}^{+}(0.97) \\
\mathrm{Mg}^{2+}(0.97)\end{array}$ & $\begin{array}{l}\mathrm{NO}_{3}^{-}(0.91) \\
\mathrm{SO}_{4}^{2-}(0.93) \\
\mathrm{Ca}^{2+}(-0.77)\end{array}$ & $\begin{array}{l}\mathrm{NH}_{4}^{+}(0.83) \\
\mathrm{OC}(0.91) \\
\mathrm{EC}(0.85)\end{array}$ & $\mathrm{PO}_{4}{ }^{3-}(0.95)$ \\
\hline Poznan, Polanka Street & $\begin{array}{c}\text { Winter } \\
25 \text { October-22 November } 2016\end{array}$ & $\begin{array}{l}\mathrm{F}^{-}(0.85) \\
\mathrm{Cl}^{-}(0.84) \\
\mathrm{OC}(0.91) \\
\mathrm{EC}(0.90)\end{array}$ & $\begin{array}{l}\mathrm{PO}_{4}^{3-}(0.96) \\
\mathrm{Ca}^{2+}(0.82)\end{array}$ & $\mathrm{Mg}^{2+}(0.87)$ & $\begin{array}{l}\mathrm{NO}_{3}{ }^{-}(0.88) \\
\mathrm{SO}_{4}^{2-}(0.81) \\
\mathrm{NH}_{4}+(0.89)\end{array}$ \\
\hline $\begin{array}{c}\text { Poznan, } \\
\text { Jana Pawla II Street }\end{array}$ & $\begin{array}{c}\text { Winter } \\
25 \text { October-22 November } 2016\end{array}$ & $\begin{array}{c}\mathrm{F}^{-}(0.89) \\
\mathrm{Cl}^{-}(0.92) \\
\mathrm{SO}_{4}^{2-}(0.72) \\
\mathrm{Na}^{+}(0.98) \\
\mathrm{K}^{+}(0.92) \\
\mathrm{Mg}^{2+}(0.95) \\
\mathrm{Ca}^{2+}(0.95)\end{array}$ & $\begin{array}{l}\text { OC }(0.95) \\
\text { EC }(0.98)\end{array}$ & $\begin{array}{l}\mathrm{NO}_{3}^{-}(0.94) \\
\mathrm{NH}_{4}^{+}(0.87)\end{array}$ & - \\
\hline Poznan, Polanka Street & $\begin{array}{l}\text { Summer } \\
5 \text { June-2 July } 2017\end{array}$ & $\begin{array}{l}\mathrm{Cl}^{-}(0.88) \\
\mathrm{NO}_{3}^{-}(0.91) \\
\mathrm{PO}_{4}^{3-}(0.93) \\
\mathrm{Na}^{+}(0.93)\end{array}$ & $\begin{array}{l}\mathrm{SO}_{4}^{2-}(0.93) \\
\mathrm{NH}_{4}^{+}(0.91) \\
\mathrm{OC}(0.80)\end{array}$ & $\mathrm{Ca}^{2+}(0.84)$ & $\begin{array}{c}\mathrm{F}^{-}(0.72) \\
\mathrm{Mg}^{2+}(0.88)\end{array}$ \\
\hline $\begin{array}{c}\text { Poznan, } \\
\text { Jana Pawla II Street }\end{array}$ & $\begin{array}{c}\text { Summer } \\
5 \text { June-2 July } 2017\end{array}$ & $\begin{array}{l}\mathrm{SO}_{4}^{2-}(0.85) \\
\mathrm{NH}_{4}^{+}(0.96)\end{array}$ & $\begin{array}{l}\mathrm{PO}_{4}^{3-}(0.88) \\
\mathrm{Mg}^{2+}(0.81) \\
\mathrm{Ca}^{2+}(0.83)\end{array}$ & $\mathrm{F}^{-}(0.95)$ & $\begin{array}{l}\mathrm{Cl}^{-}(0.73) \\
\mathrm{Na}^{+}(0.93)\end{array}$ \\
\hline
\end{tabular}

In the case of Wrocław, the conducted analyses (Table 4) enabled the identification of four main components in the heating season. In the Principal Component (PC) 1 (Factor 1), for the heating season, there was a correlation between the main component and $\mathrm{F}^{-}$and $\mathrm{Cl}^{-}$anions, and $\mathrm{Na}^{+}, \mathrm{K}^{+}$and $\mathrm{Mg}^{2+}$ cations. Such a relationship was strengthened by the correlation between the main component and $\mathrm{Ca}^{2+}$ cations in the $\mathrm{PC} 2$ and $\mathrm{NH}_{4}{ }^{+}, \mathrm{OC}$ and $\mathrm{EC}$ in the PC 3 . This proves the influence of combustion processes and soil resuspension as sources of $\mathrm{PM}_{2.5}$ particulate matter [58]. In the non-heating season, there was a correlation for $\mathrm{Mg}^{2+}, \mathrm{SO}_{4}{ }^{2-}$ and $\mathrm{NH}_{4}{ }^{+}$identified in the PC 1 that indicates the influence of emissions originating from fuel combustion processes and also the influence of secondary aerosols $[48,58,59]$. For stations located in Poznan, the analysis revealed that in the winter season at the station at Polanka Street (Station 7), the most significant for the first PC were OC, EC, $\mathrm{F}^{-}, \mathrm{Cl}^{-}$and $\mathrm{K}^{+}$, whereas at the station at Jana Pawła II (Station 8), the most important for the first PC were: $\mathrm{F}^{-}, \mathrm{Cl}^{-}, \mathrm{SO}_{4}{ }^{2-}, \mathrm{K}^{+}, \mathrm{Mg}^{2+}$ and $\mathrm{Ca}^{2+}$, which indicates combustion processes as the source of the considered pollutants. A high percentage of $\mathrm{Na}^{+}$and $\mathrm{Cl}^{-}$in the fourth PC may also indicate the influence of salting (in the winter season) on the composition of particulate matter at the given station [60]. PC 2, singled out in the analysis for the station at Polanka Street, indicates the existence of mineral dust and vegetal fragments in the content of $\mathrm{PM}_{2.5}$ particulate matter. PC 3, similarly to the case of PC 2, indicates the influence of emissions originating from fuel combustion processes in the analysis for the station at Jana Pawła II Street. In this case, the influence of road transport emissions indicates a high correlation coefficient for OC and EC. PC 4, in the case of the station at Polanka Street, as well as PC 3 from the station at Jana Pawła II Street, are related to the emission of the secondary aerosol $\mathrm{NH}_{4} \mathrm{NO}_{3}$, whose presence proves the that there are high concentrations of its precursors in atmospheric air [33,46]. In the case of 
Poznań, their presence may be attributed to both road transport and gas heating, which is used by the downtown inhabitants. In the summer season, four main PCs were singled out for both of the analyzed stations. At the station at Jana Pawła II Street, it was found that the most important components for the first $\mathrm{PC}$ were $\mathrm{SO}_{4}{ }^{2-}$ and $\mathrm{NH}_{4}{ }^{+}$, and it confirms the influence of fuel combustion on the air quality in Poznań. In the second factor, a high correlation coefficient was characteristic for $\mathrm{Ca}^{2+}, \mathrm{Mg}^{2+}$ and $\mathrm{PO}_{4}{ }^{3-}$, and in the third factor, a high correlation coefficient was characteristic for $\mathrm{F}^{-}$. This indicates the influence of mineral dust and vegetal fragments on the composition of particulate matter in the summer season at that station $[61,62]$. At the station at Polanka Street, in the two first factors, the main components that were singled out were characteristic for both liquid and solid fuel combustion. In the third and fourth factors, the main components that were singled out were characteristic of mineral dust presence. The influence on this condition in the summer season may be attributed to the floating of mineral particles originating from the surface of roads and parking lots and also to the influx of air from the Saharan terrains [48]. Nonetheless, it is possible to observe a difference between the origin of particulate matter in the heating and non-heating seasons. In the winter season, fuel combustion remains a dominating source of emissions and at the same time a factor influencing the composition of particulate matter. In the summer season, the presence of mineral dust, which often flows from distant areas $[46,60]$, is very important.
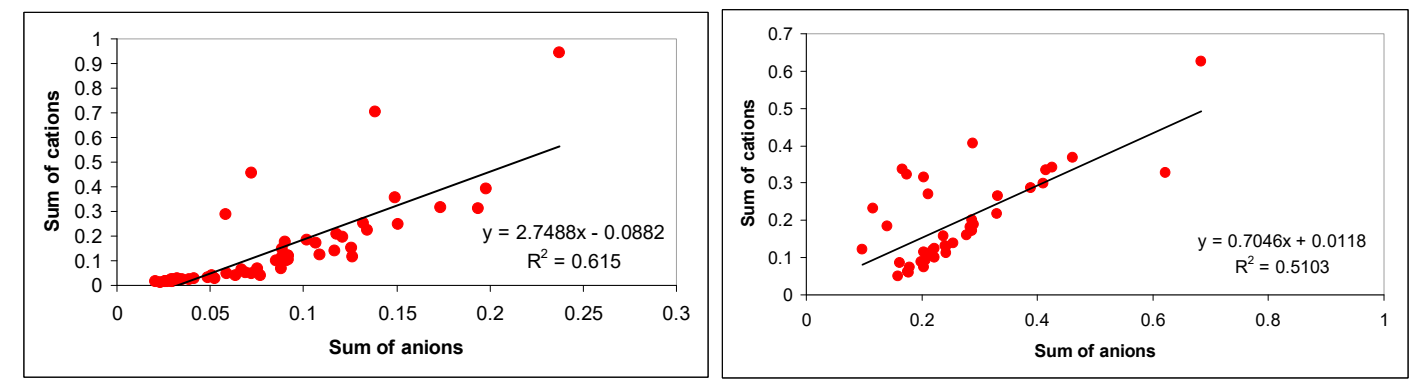

a)

b)
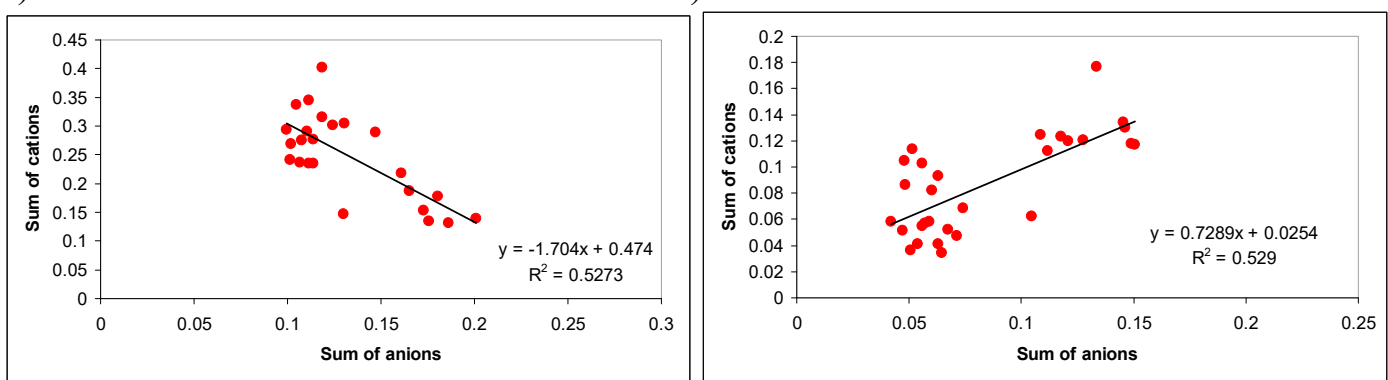

c)

d)
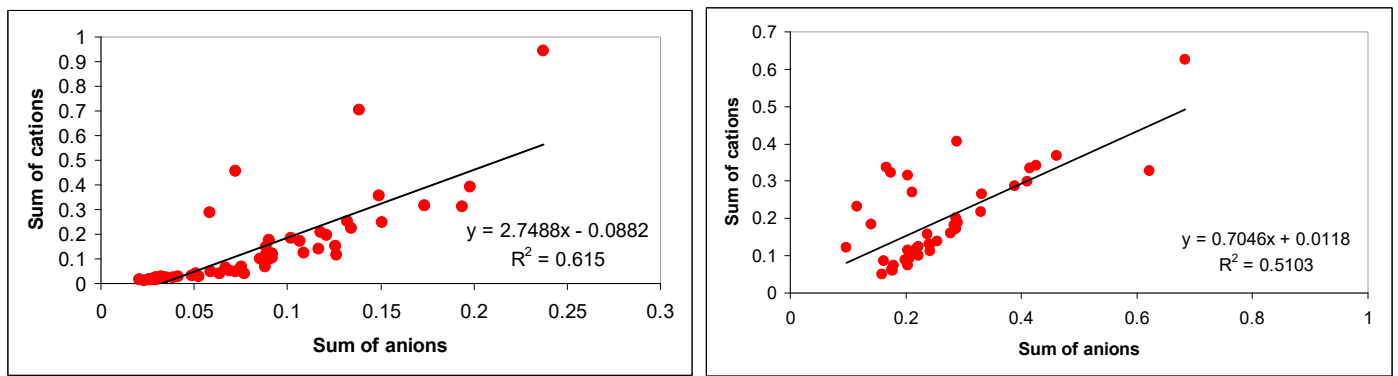

e)

f)

Figure 3. Sum of cations $\left(\Sigma\right.$ cations in $\mu$ eq $\left.\mathrm{m}^{-3}\right)$ vs. sum of anions $\left(\sum\right.$ anions in $\mu$ eq $\left.\mathrm{m}^{-3}\right)$ and a trendline equation (the result of linear regression is described using $\mathrm{R}^{2}$; the coefficient of determination) in Wroclaw at Kosiby Street in spring-summer (a); at Kosiby Street in winter (b); in Poznań at Polanka Street in winter (c); at Jana Pawla II Street in winter (d); at Polanka Street in summer (e); at Jana Pawla II Street in summer (f). 
From analyzing the linear dependence sum of $\mathrm{PM}_{2.5}$-bound cations vs. the analyses sum of $\mathrm{PM}_{2.5}$-bound anions in all cases (locations and seasons), a statistically significant $(p<0.05)$ linear relationship of $\Sigma$ cations and $\Sigma$ anions was observed (Figure 3). Generally, it can be seen that the $\Sigma$ cations/ $\Sigma$ anions ratio reached values below one in the winter season and higher than one in the summer season. Specifically, in Poznań, the average values of the $\Sigma$ cations $/ \Sigma$ anions ratio in winter and summer were at 0.33 and 2 at Polanka Street, and 2 and 1.1 at John Paul II Street, respectively. In the case of Wrocław, at Kosiby Street, the average values of the $\Sigma$ cations/ $/$ anions ratio were at 1.4 , and 0.74 in winter. It can be stated that in winter seasons in the studied atmospheric aerosol, both in Poznan and Wrocław, mainly sulfate and nitrogen anions forming inorganic secondary aerosols predominated. In the summer season, in both considered urban locations, mineral aerosol components (calcium, potassium and magnesium) had a clear contribution. During this period, the aerosol probably have an alkaline characteristic, and the emission of mineral dusts (road dust, soil) can definitely contribute to the $\mathrm{PM}_{2.5}$ concentration.

\section{Summary}

In the analyzed measuring period, the concentrations of particulate matter were high; the highest $\mathrm{PM}_{2.5}$ concentration in Wrocław was found in the winter of $2016\left(70.12 \mu \mathrm{g} / \mathrm{m}^{3}\right)$ and in Poznan in the autumn-winter of $2016\left(88.5 \mu \mathrm{g} / \mathrm{m}^{3}\right)$. Organic and elemental carbon were macro elements in both locations regardless of the measurement season. Among the ions determined, the highest concentrations were generally recorded for $\mathrm{PO}_{4}{ }^{3-}, \mathrm{SO}_{4}{ }^{2-}, \mathrm{Na}^{+}, \mathrm{NH}_{4}{ }^{+}$and $\mathrm{F}^{-}$.

It has been shown that the primary sources of fine PM emissions in both areas are the burning of fossil fuels, biomass and liquid fuels in automotive engines. In addition, in the measurement campaign conducted in Poznań, a clear impact of gaseous transformations of PM precursors on PM concentrations in the air was observed. In both locations, in selected seasons, a possible contribution of mineral matter (road and soil dust) in PM was also revealed.

Author Contributions: Conceptualization, I.S.; Data curation, A.C.-S., Ł.P., B.M. and W.R.-K.; Formal analysis, I.S. and W.R.-K.; Investigation, I.S., A.C.-S., Ł.P., B.M. and W.R.-K.; Methodology, I.S., A.C.-S., B.M. and W.R.-K.; Supervision, I.S.; Validation, W.R.-K.; Visualization, A.C.-S.; Writing - original draft, I.S., A.C.-S. and Ł.P.; Writing review \& editing, I.S. and W.R.-K.

Funding: Research was co-financed from funds No. 0402/0209/15 and 0402/0088/16 from a special purpose grant awarded to the Faculty of Environmental Engineering of the Wrocław University of Science and Technology (W-7) by the Minister of Science and Higher Education for conducting scientific research or development works and related tasks development of young scientists and doctoral students.

Conflicts of Interest: The authors declare no conflict of interest

\section{References}

1. European Environment Agency. Air Quality in Europe-2016 Report; Publications Office of the European Union: Luxemburg, 2016.

2. Oberdörster, G.; Sharp, Z.; Atudorei, V.; Elder, A.; Gelein, R.; Lunts, A.; Kreyling, W.; Cox, C. Extrapulmonary translocation of ultrafine carbon particles following whole-body inhalation exposure of rats. J. Toxicol. Environ. Health Part A 2002, 65, 1531-1543. [CrossRef] [PubMed]

3. Wilson, M. Interactions between Ultrafine Particles and Transition Metals in Vivo and in Vitro. Toxicol. Appl. Pharm. 2002, 184, 172-179. [CrossRef]

4. Gwinn, M.R.; Vallyathan, V. Nanoparticles. Health effects-Pros and cons. Environ. Health Perspect. 2006, 114, 1818. [CrossRef] [PubMed]

5. Lu, S.; Zhang, W.; Zhang, R.; Liu, P.; Wang, Q.; Shang, Y.; Wu, M.; Donaldson, K.; Wang, Q. Comparison of cellular toxicity caused by ambient ultrafine particles and engineered metal oxide nanoparticles. Part. Fibre Toxicol. 2015, 12, 5. [CrossRef]

6. Corsini, E.; Vecchi, R.; Marabini, L.; Fermo, P.; Becagli, S.; Bernardoni, V.; Caruso, D.; Corbella, L.; Dell'Acqua, M.; Galli, C.L.; et al. The chemical composition of ultrafine particles and associated biological effects at an alpine town impacted by wood burning. Sci. Total Environ. 2017, 587, 223-231. [CrossRef] 
7. Widziewicz, K.; Rogula-Kozłowska, W. Urban environment as a factor modulating metals deposition in the respiratory track and associated cancer risk. Atmos. Pollut. Res. 2017, 9, 399-410. [CrossRef]

8. European Environment Agency. Air Quality in Europe-2018 Report; Publications Office of the European Union: Luxemburg, 2018. [CrossRef]

9. Chlebowska-Styś, A.; Kobus, D.; Pachurka, Ł.; Sówka, I. Analysis of concentrations trends and origins of PM 10 in selected European cities. E3S Web Conf. 2017, 17, 13. [CrossRef]

10. Chlebowska-Styś, A.; Sówka, I.; Pachurka, Ł. Analysis of air quality in selected polish cities. In Człowiek a Środowisko: Wzajemne Oddziaływanie = Man vs Environment: Interaction; Chmielewski, J., Żeber-Dzikowska, I., Gworek, B., Eds.; Instytut Ochrony Środowiska, Państwowy Instytut Badawczy: Warszawa, Poland, 2016; pp. 103-120. (In Polish)

11. Błaszczak, B.; Rogula-Kozłowska, W.; Mathews, B.; Juda-Rezler, K.; Klejnowski, K.; Rogula-Kopiec, P. Chemical Compositions of PM2.5 at Two Non-Urban Sites from the Polluted Region in Europe. Aerosol Air Qual. Res. 2016, 16, 2333-2348. [CrossRef]

12. Rogula-Kozłowska, W.; Majewski, G.; Czechowski, P.O.; Rogula-Kopiec, P. Analysis of the data set from a two-year observation of the ambient water-soluble ions bound to four particulate matter fractions in an urban background site in southern Poland. Environ. Prot. Eng. 2017, 43, 137-149. [CrossRef]

13. Czarnecka, M.; Kalbarczyk, R. Weather conditions determining variability of suspended particulate matter concentration in Pomerania. Acta Agroph 2008, 11, 357-368.

14. Juda-Rezler, K.; Reizer, M.; Oudinet, J.-P. Determination and analysis of PM10 source apportionment during episodes of air pollution in Central Eastern European urban areas: The case of wintertime 2006. Atmos. Environ. 2011, 45, 6557-6566. [CrossRef]

15. Chlebowska-Styś, A.; Kobus, D.; Zathey, M.; Sówka, I. The impact of road transport on air quality in selected Polish cities. E3S Web Conf. 2017, 22, 1-8.

16. Rogula-Kozłowska, W. Size-segregated urban particulate matter: Mass closure, chemical composition, and primary and secondary matter content. Air Qual. Atmos. Health 2016, 9, 533-550. [CrossRef]

17. Cembrzyńka, J.; Krakowiak, E.; Brewczyński, P.Z. Zanieczyszczenie powietrza pyłem zawieszonym PM10 oraz PM2,5 w warunkach silnej antropopresji na przykładzie miasta Sosnowiec. Med. Środowiskowa Environ. Med. 2012, 15, 31-38.

18. Chlebowska-Styś, A.; Sówka, I.; Pachurka, Ł. Analiza składu pyłu zawieszonego PM10 na stacji tła miejskiego w Pile. In Interdyscyplinarne Zagadnienia w Inżynierii i Ochronie Środowiska; Kaźmierczak, B., Kotowski, A., Piekarska, K., Eds.; Oficyna Wydawnicza Politechniki Wrocławskiej: Wrocław, Poland, 2016; pp. 36-53. (In Polish)

19. Jeong, C.H.J.; Jon, M.; Wang, J.M.; Greg, J.; Evans, G.J. Source apportionment of particulate matter in Europe: A review of methods and results. J. Aerosol Sci. 2008, 39, 827-849. [CrossRef]

20. Kozielska, B.; Kozłowska, W.R.; Pastuszka, J.S. Traffic emission effects on ambient air pollution by PM2.5-related PAH in Upper Silesia, Poland. Int. J. Environ. Pollut. 2013, 53, 245. [CrossRef]

21. Rogula-Kozłowska, W.; Kuskowska, K.; Ogrodnik, P.; Penkała, M. Traffic-generated changes in the elemental profile of urban coarse dust at a highway and crossroads. E3S Web Conf. 2018, 45, 00074. [CrossRef]

22. Polish Journal of Laws 2012, item 1031: Regulation of the Minister of the Environment of 24 August 2012 on the Levels of Certain Substances in the Air. Available online: http://prawo.sejm.gov.pl/isap.nsf/DocDetails. xsp?id=WDU20120001031 (accessed on 10 September 2019).

23. Almeida, S.M.; Pio, C.; Freitas, M.; Reis, M.; Trancoso, M.; Pio, C.; Reis, M. Approaching PM2.5 and PM2.5-10 source apportionment by mass balance analysis, principal component analysis and particle size distribution. Sci. Total Environ. 2006, 368, 663-674. [CrossRef]

24. Almeida, S.M.; Pio, C.; Freitas, M.; Reis, M.A.; Trancoso, M. Source apportionment of fine and coarse particulate matter in a sub-urban area at the Western European Coast. Atmos. Environ. 2005, 39, 3127-3138. [CrossRef]

25. Masiol, M.; Squizzato, S.; Ceccato, D.; Rampazzo, G.; Pavoni, B. A chemometric approach to determine local and regional sources of PM10 and its geochemical composition in a coastal area. Atmos. Environ. 2012, 54, 127-133. [CrossRef]

26. Samek, L.; Zwoździak, A.; Sówka, I. Chemical characterization and source identification of particulate matter PM10 in rural and urban site in Poland. Environ. Prot. Eng. 2013, 4, 91-103. [CrossRef]

27. Vianaab, M.; Querolb, X.; Alastueyb, A.; Gilc, J.I.; Menéndezc, M. Identification of PM sources by principal component analysis (PCA) coupled with wind direction data. Chemosphere 2006, 65, 2411-2418. [CrossRef] 
28. Majewski, G.; Rogula-Kozłowska, W.; Czechowski, P.O.; Badyda, A.; Brandyk, A. The Impact of Selected Parameters on Visibility: First Results from a Long-Term Campaign in Warsaw, Poland. Atmosphere 2015, 6, 1154-1174. [CrossRef]

29. Rogula-Kozłowska, W.; Majewski, G.; Czechowski, P.O. The size distribution and origin of elements bound to ambient particles: A case study of a Polish urban area. Environ. Monit. Assess. 2015, 187, 240. [CrossRef]

30. Majewski, G.; Rogula-Kozłowska, W. The elemental composition and origin of fine ambient particles in the largest Polish conurbation: First results from the short-term winter campaign. Theor. Appl. Climatol. 2016, 125, 79-92. [CrossRef]

31. Dragon, K.; Jażdzewska, J. Analiza czynnikowa jako metoda identyfikacji procesów kształtujących skład chemiczny wód podziemnych. Przegląd Geol. 2015, 63, 688-693. (In Polish)

32. Chlebowska-Styś, A.; Sówka, I. Trendy zmian stężeń pyłów (PM10 i PM2.5) oraz benzo(a)pirenu na przykładzie wybranych miast Wielkopolski. In Interdyscyplinarne Zagadnienia w Inżynierii i Ochronie Środowiska; Kotowski, A., Piekarska, K., Kaźmierczak, B., Eds.; Oficyna Wydawnicza Politechniki Wrocławskiej: Wrocław, Poland, 2015; pp. 40-53. (In Polish)

33. Rogula-Kozłowska, W.; Pastuszka, J.S.; Talik, E. Influence of Vehicular Traffic on Concentration and Particle Surface Composition of PM10 and PM2.5 in Zabrze, Poland. Pol. J. Environ. Stud. 2008, 17, 539-548.

34. Pachurka, Ł.; Sówka, I.; Rogula-Kozłowska, W.; Mathews, B.; Chlebowska-Styś, A.; Zwoździak, A. Analiza składu chemicznego i pochodzenia pyłu zawieszonego na wybranym obszarze miasta Wrocławia wraz z określeniem potencjalnego wpływu na zdrowie mieszkańców. In Determinanty Zdrowia = Health Determinants; Chmielewski, J., Florek-Łuszczki, M., Szpringer, M., Eds.; Instytut Ochrony Środowiska, Państwowy Instytut Badawczy: Warszawa, Poland, 2016; pp. 133-141. (In Polish)

35. World Health Organization. Health Risk Assessment of Air Pollution-General Principles; WHO Regional Office for Europe: Copenhagen, Denmark, 2016.

36. Chłopek, Z. Identyfikacja Modeli Imisji Czastek Stałych PM2.5 i PM1; Zeszyty Naukowe Instytutu Pojazdów: Warsaw, Poland, 2012; pp. 157-164.

37. Rogula-Kozłowska, W.; Klejnowski, K. Submicrometer Aerosol in Rural and Urban Backgrounds in Southern Poland: Primary and Secondary Components of PM1. Bull. Environ. Contam. Toxicol. 2013, 90, 103. [CrossRef]

38. Allen, A.; Nemitz, E.; Shi, J.; Harrison, R.; Greenwood, J. Size distributions of trace metals in atmospheric aerosols in the United Kingdom. Atmos. Environ. 2001, 35, 4581-4591. [CrossRef]

39. Rogula-Kozłowska, W.; Klejnowski, K.; Rogula-Kopiec, P.; Ośródka, L.; Krajny, E.; Błaszczak, E.; Mathews, B. Spatial and seasonal variability of the mass concentration and chemical composition of PM2.5 in Poland. Air Qual. Atmos. Health 2014, 7, 41-58. [CrossRef]

40. Rogula-Kozłowska, W.; Majewski, G.; Błaszczak, B.; Klejnowski, K.; Rogula-Kopiec, P. Origin-Oriented Elemental Profile of Fine Ambient Particulate Matter in Central European Suburban Conditions. Int. J. Environ. Res. Public Health 2016, 13, 715. [CrossRef] [PubMed]

41. Pachurka, Ł.; Sówka, I.; Rogula-Kozłowska, W.; Chlebowska-Styś, A.; Zwoździak, A. Assessment of the health risks associated with inhalation exposure to cadmium, arsenic and nickel in selected cities of Lower Silesia. In Proceedings of the Ukrainian-Polish Conference: The Problems of Air Pollution and Purification: Control, Monitoring, Catalytic, Photocatalytic and Sorption Methods of Treatment, Kyiv, Ukraine, 6-8 November 2016.

42. Pachurka, Ł.; Rogula-Kozłowska, W.; Chlebowska-Styś, A.; Nych, A.; Zwoździak, A. Exposure of urban agglomeration population to the selected components of PM1emitted from low emission sources. E3S Web Conf. 2017, 17, 71. [CrossRef]

43. Pachurka, Ł.; Sówka, I. Wpływ zanieczyszczeń powietrza pyłem zawieszonym na ryzyko potencjalnej utraty zdrowia mieszkańców Wrocławia. In Środowiskowe i Zawodowe Zagrożenia Zdrowia-Wiedza i Praktyka = Environmental and Occupational Health Hazards-Knowledge and Practice; Chmielewski, J., Pawlas, N., Szpringer, M., Eds.; Zakład Poligraficzno-Wydawniczy "Magraf": Kielce, Poland, 2016; pp. 43-56. (In Polish)

44. Majewski, G.; Rogula-Kozłowska, W.; Rozbicka, K.; Rogula-Kopiec, P.; Mathews, B.; Brandyk, A. Concentration, Chemical Composition and Origin of PM1: Results from the First Long-term Measurement Campaign in Warsaw (Poland). Aerosol Air Qual. Res. 2018, 18, 636-654. [CrossRef]

45. Rogula-Kozłowska, W.; Kozielska, B.; Klejnowski, K. Hazardous Compounds in Urban Pm in the Central Part of Upper Silesia (Poland) in Winter. Arch. Environ. Prot. 2013, 39, 53-65. [CrossRef] 
46. Institute of Environmental Engineering of the Polish Academy of Sciences; Institute of Ecology of Industrial Areas; Institute of Meteorology and Water Management PIB; Institute of Environmental Protection PIB. Analysis of the State of Air Pollution with Dust PM10 and PM2.5 Taking into Account the Chemical Composition of Dust and the Impact of Natural Sources-A Synthetic Report; Inspection for Environmental Protection; Institute of Environmental Protection PIB: Zabrze, Poland, 2011. (In Polish)

47. Lewandowska, A.; Falkowska, L.; Jóźwik, J. Factors determining the fluctuation of fluoride concentrations in PM10 aerosols in the urbanized coastal area of the Baltic Sea (Gdynia, Poland). Environ. Sci. Pollut. Res. 2013, 20, 6109-6118. [CrossRef]

48. AirBase Official Website. Available online: https://www.eea.europa.eu/data-and-maps/data/airbasetheeuropean-air-quality-database-7 (accessed on 25 August 2017).

49. Schwarz, J.; Cusack, M.; Karban, J.; Chalupní cková, E.; Havránek, V.; Smolík, J.; Ždímal, V. PM2.5 chemical composition at a rural background site in Central Europe, including correlation and air mass back trajectory analysis. Atmos. Res. 2016, 176-177, 108-120. [CrossRef]

50. EBAS Database. Available online: http://ebas.nilu.no (accessed on 25 February 2014).

51. Rogula-Kozłowska, W.; Klejnowski, K.; Rogula-Kopiec, P.; Mathews, B.; Szopa, S. A Study on the Seasonal Mass Closure of Ambient Fine and Coarse Dusts in Zabrze, Poland. Bull. Environ. Contam. Toxicol. 2012, 88, 722-729. [CrossRef]

52. Makkonen, U.; Virkkula, A.; Mäntykenttä, J.; Hakola, H.; Keronen, P.; Vakkari, V.; Aalto, P.P. Semi-continuous gas and inorganic aerosol measurements at a Finnish urban site: Comparisons with filters, nitrogen in aerosol and gas phases, and aerosol acidity. Atmos. Chem. Phys. Discuss. 2012, 12, 5617-5631. [CrossRef]

53. Ravindra, K.; Stranger, M.; Van Grieken, R.; Grieken, R. Chemical characterization and multivariate analysis of atmospheric PM2.5 particles. J. Atmos. Chem. 2008, 59, 199-218. [CrossRef]

54. Kfoury, A.; LeDoux, F.; Roche, C.; Delmaire, G.; Roussel, G.; Courcot, D. PM2.5 source apportionment in a French urban coastal site under steelworks emission influences using constrained non-negative matrix factorization receptor model. J. Environ. Sci. 2016, 40, 114-128. [CrossRef]

55. Szigeti, T.; Óvári, M.; Dunster, C.; Kelly, F.J.; Lucarelli, F.; Záray, G. Changes in chemical composition and oxidative potential of urban PM2.5 between 2010 and 2013 in Hungary. Sci. Total Environ. 2015, 518, 534-544. [CrossRef] [PubMed]

56. Tolis, E.I.; Saraga, D.E.; Lytra, M.K.; Papathanasiou, A.C.; Bougaidis, P.N.; Prekas-Patronakis, O.E.; Ioannidis, I.I.; Bartzis, J.G. Concentration and chemical composition of PM2.5 for a one-year period at Thessaloniki, Greece: A comparison between city and port area. Atmos. Environ. 2015, 113, 197-207. [CrossRef]

57. Mirante, F.; Salvador, P.; Pio, C.; Alves, C.; Artíñano, B.; Caseiro, A.; Revuelta, M.A. Size fractionated aerosol composition at roadside and background environments in the Madrid urban atmosphere. Atmos. Res. 2014, 138, 278-292. [CrossRef]

58. Rogula-Kozłowska, W.; Rogula-Kopiec, P.; Mathews, B.; Klejnowski, K. Effects of road traffic on the ambient concentrations of three PM fractions and their main components in a large Upper Silesian city. Annals of Warsaw University of Life Sciences-SGGW. Land Reclam. 2013, 45, 243-253.

59. Klejnowski, K.; Rogula-Kopiec, P.; Rogula-Kozłowska, W. Ocena zawartości wtórnego węgla organicznego w drobnym pyle zawieszonym w wybranych obszarach województwa śląskiego. Przegląd Nauk. Inżynieria Ksztattowanie Środowiska Sci. Rev. Eng. Environ. Sci. 2014, 66, 347-359.

60. Degórska, A. Sources of air pollution with dust. In Fine dust in the atmosphere. In Compendium of Knowledge about Air Pollution in Particulate Matter in Poland; Juda-Rezler, K., Toczko, B., Eds.; Chief Inspectorate for Environmental Protection: Warsaw, Poland, 2016; pp. 22-30. (In Polish)

61. Engelbrecht, J.P.; Moosmüller, H.; Pincock, S.; Jayanty, R.K.M.; Lersch, T.; Casuccio, G. Technical note: Mineralogical, chemical, morphological, and optical. Atmos. Chem. Phys. 2016, 16, 10809-10830. [CrossRef]

62. Karydis, V.A.; Tsimpidi, A.P.; Pozzer, A.; Astitha, M.; Lelieveld, J. Effects of mineral dust on global atmospheric nitrate concentrations. Atmos. Chem. Phys. Discuss. 2016, 16, 1491-1509. [CrossRef]

(C) 2019 by the authors. Licensee MDPI, Basel, Switzerland. This article is an open access article distributed under the terms and conditions of the Creative Commons Attribution (CC BY) license (http://creativecommons.org/licenses/by/4.0/). 